$\mathrm{DOE} / \mathrm{CS} / 50009-01$

$\frac{178}{16} 40$

\title{
Opportunities for Coal to \\ Methanol Conversion
}

April 1980

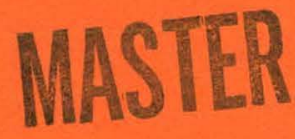

Prepared for:

U.S. Department of Energy

Assistant Secretary for

Conservation and Solar Applications

Office of Transportation Programs

Under Contract No. AC01-79CS50009

\section{DOE \\ Alcohol \\ Fuels \\ Program}

Alternative Fuels Utilization Program 


\section{DISCLAIMER}

This report was prepared as an account of work sponsored by an agency of the United States Government. Neither the United States Government nor any agency Thereof, nor any of their employees, makes any warranty, express or implied, or assumes any legal liability or responsibility for the accuracy, completeness, or usefulness of any information, apparatus, product, or process disclosed, or represents that its use would not infringe privately owned rights. Reference herein to any specific commercial product, process, or service by trade name, trademark, manufacturer, or otherwise does not necessarily constitute or imply its endorsement, recommendation, or favoring by the United States Government or any agency thereof. The views and opinions of authors expressed herein do not necessarily state or reflect those of the United States Government or any agency thereof. 


\section{DISCLAIMER}

Portions of this document may be illegible in electronic image products. Images are produced from the best available original document. 


\section{NOTICE}

This report was prepared as an account of work sponsored by the United States Government. Neither the United States nor the United States Department of Energy, nor any of their employees, makes any warranty, express or implied, or assumes any legal liability or responsibility for the accuracy, completeness, or usefulness of any information, apparatus, product, or process disclosed, or represents that its use would not infringe privately owned rights. Reference herein to any specific commercial product, process, or service by trade name, mark, manufacturer, or otherwise, does not necessarily constitute or imply its endorsement, recommendation, or favoring by the United States Government or any agency thereof. The views and opinions of authors expressed herein do not necessarily state or reflect those of the United States Government or any agency thereof.

\section{Available from:}

National Technical Information Service (NTIS) U.S. Department of Commerce 5285, Port Royal Road

Springfield, Virginia 22161

Price: Printed copy: $\$ 8.00$

Microfiche: $\$ 4.00$ 
$\mathrm{DOE} / \mathrm{CS} / 50009-01$

Dist. Category UC-96

\section{Opportunities for Coal to Methanol Conversion}

April 1980

Prepared for:

U.S. Department of Energy

Assistant Secretary for

Conservation and Solar Applications

Office of Transportation Programs

Washington, D.C. 20585

Prepared by:

American Energy Research Company

McLean, Virginia

Under Contract No. AC01-79CS50009 
TABLE OF CONTENTS

SUMMARY

INTRODUCTION

PLAN OF APPROACH

COAL SOURCES

COAL REFUSE

COAL GASIFICATION

DEMAND

costs

DISTRIBUTION

ENVIRONMENTAL IMPACT

SOCIOLOGIC AND INSTITUTIONAL IMPACTS

APPENDICES

BIBLIOGRAPHY
Page

1

2

5

8

16

29

36

40

50

54

58

60

66 


\section{SUMMARY}

The accumulations of mining residues in the anthracite coal regions of Pennsylvania offer a unique opportunity to convert the coal content into methanol that could be utilized in that area as an alternative to gasoline or to extend the. supplies through blending. Additional demand may develop through the requirements of public utility gas turbines 1ocated in that region.

The cost to run this refuse through coal preparation plants may result in a clean coal at about $\$ 17.00$ per ton. After gasification and synthesis in a 5000 ton per day facility, a cost of methanol of approximately $\$ 3.84$ per million Btu is obtained using utility financing. If the coal is to be brought in by truck or rail from a distance of approximately 60 miles, the cost of methanol would range between $\$ 4.64$ and $\$ 5.50$ per million Btu depending upon the mode of transpurtation.

The distribution costs to move the methanol from the synthesis plant to the pump could add, at a minimum, $\$ 2.36$ per million Btu to the cost.

In total, the delivered cost at the pump fur methanol produced from coal mining wastes could range between $\$ 6.20$ and $\$ 7.86$ per million Btu. 


\section{INTRODUCTION}

In the search for a non-petroleum energy base for transportation fuels in this country, alcohols have been receiving considerable attention as liquid fuels to supplement the nation's gasoline supplies. In particular, methanol with its favorable chemical and physical properties has been the subject of intensive study regarding engine design and performance. The level of performance and reliability with $100 \%$ methanol have been excellent. Thermal efficiency in engines has been high owing to favorable thermochemical properties, leaner limits of combustion, and higher compression ratios. Exhaust emissions of hydrocarbons and carbon monoxide are virtually the same as those of gasoline at the same equivalent air-fuel mixture. Aldehyde emissions are present but ale markedly reduced by small quantitios of walies. The oxides of nitrogen in the emissions are found to be lower than with gasoline particularly at lean air-fuel mixtures. Such characteristics as driveability are very good other than low temperature starting.

Alcohol-gasoline blends in general exhibit better thermal efficiency than gasoline particularly with an incrcas.ing alcohol content of the blend. Exhaust emissions of hydrocarbons and carbon monoxide are reduced compared to gasoline for rich mixtures; nitrogen oxides are also lower. Driveability is comparable to gasoline at equivalent air-fuel ratios. Aldehyde emissions occur with these blends but have 
been reported not to be objectionable.

A number of the differences that are found to exist between gasoline and methanol stem from the presence of oxygen in the alcohol molecule. This manifests itself in connection with its solubility and volatility in gasoline. The methanol molecule owing to its more significant polar configuration than that of the higher alcohols, will dissolve less readily in the paraffin hydrocarbons. Furthex, in the presence of small amounts of water in a gasoline-methanol mixture, bonds may result in a phase separation that is undesirable from the standpoint of achieving good combustion.

The characteristic of methanol that lends itself to being obtained from virtually any material containing carbon; hydrogen, and oxygen has proven to be one of its most appealing properties. Sufficient exploratory studies and developments have been performed to show convincingly that it can be derived readily from a wide array of abundant raw materials such as coal, wood, oil shale, tar sand, agriculture and forest harvest wastes, peat, feedlot manure, and municip̈al solid waste. Further, the production technology and economics are most encouraging for the early commercial production from one or more sources of raw materials.

The principal difficulty assooiated with all synthetic fuels in the U.S. economy is that the source of the raw material must be very large. The total U.S. energy demand is currently appruximately 10 millinn barrels per day of crude 
oil equivalent, of which 19.5 million barrels is met by U.S. sources and foreign oil imports. The U.S., Western Europe, and Japan domestic petroleum demands are shown in Figure ${ }^{4} 1^{5}$. Fuel needs of U.S. highway vehicles account for about 7 million barrels per day. Of the available domestic resources, only coal and oil shale are sufficient to singularly support the fuel requirements of these highway vehicles. A fraction of the known recoverable 300 billion tons of coal in the U.S. or the 50 billion bbls. in oil shale ${ }^{7}$ would be sufficient to provide vehicle fuels to meet foreseable demand for many years.

Economics will clearly play a major role in any substantial program to make methanol from coal. The conversion process selected; plant siting, coal type and cost, construction costs, water availability, and financiny methods all intluence the cost of methanol. An earlier investigation 6 of producing methanol from strip mined western U.S. coal showed that cost differences of as much as 60 cents per million Btu could result between a utility financed apprnarh and an investor financed discounted cash flow method. In addition, the social, environmental, and institutional problems surrounding the development of processing facilities as well as those associated with the methanol distribution involve substantial costs that must be recognized in the overall econumic assessment of the total program. 7 
United States, Western Europe, and Japan

Petroleum Domestic Demand

(Millions of Barrels Daily)

$\mathrm{MMB} / \mathrm{D}$

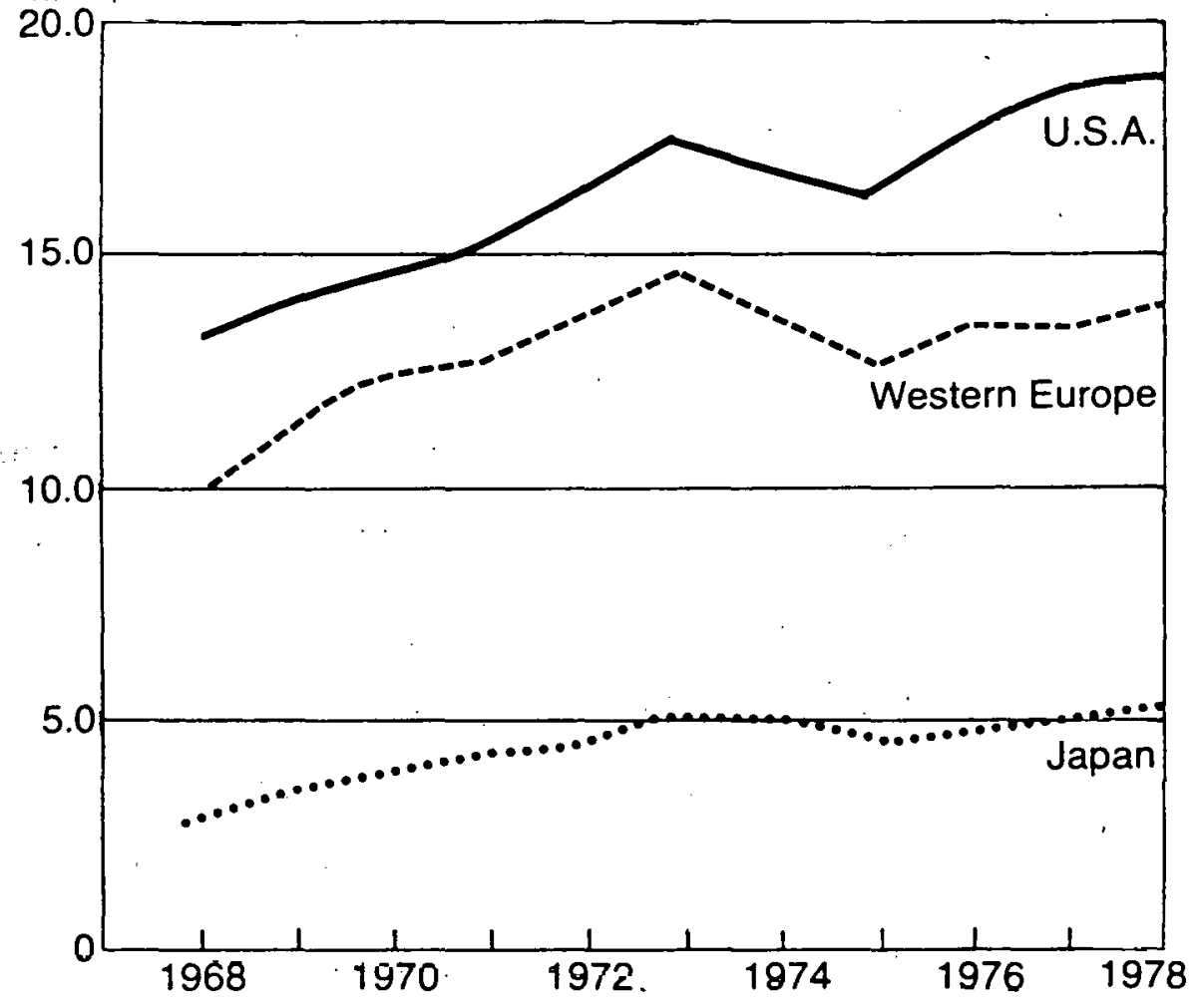

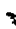

Figure 1. 
PLAN OF APPROACH

The essential elements in this program of the production of methanol from coal center around the unique opportunity to utilize the coal wastes from 150 years of Pennsylvania anthracite mining $1,2,8,9$ These refuse banks contain considerable amounts of coal that were left behind in the course of underground mining during those years. Currently, these banks are being reworked to utilize the coal for fuel purposes $10,11,12$ and for export. The cost of bringing this coal to the surface 'from the underground mine has been paid. It is expected that these residues can be handled economically and converted to methanol at a plant site nearby. If it can be consumed in the same general area, there should be overall economies both in the production and the distribution of methanol. There are also a number of peripheral benefits to bo gainen by undertaking such a program. Principal among these is the fact that many of these refuse banks are in the Illajor cities of the region or are within a few miles of the $13,14,15$

centers of population. They occupy over 12,000 acres of land which could have considerable commercial and industrial $16,17,18$ value if cleared. In addition, the region is economically depressed since the market is limited for anthracite owing to the growth of the strip mining industries of West Virginia, Ohio, Kentucky and the far West. The social climate is favorable for the development of an industry that would provide additional economic support lo the reginn. 
A 5000 tons per day methanol plant using coal as feed-

$$
6,7
$$

stock would require about 8000 tons per day of coal: Although a single plant is expected to be able to gasify and synthesize that quantity of methanol, a single coal preparation plant is not expected to be able to meet the coal requirement using coal refuse bank material. Consequently, it will be necessary, to use three or four preparation plants, the output of which will feed the methanol plant. It would be planned to locate one preparation plant near the methanol plant and the other three in the general area of heavy concentration of the coal banks. The cleaned coal from the nearby preparation plant would be available on site and could be moved by conveyor. The other three preparation plants would need to transport cleaned coal ot the gasifier.

In addition, it is expected contracl with large strip mining coal operators in this region's southern field to supply, over possibly 15 years, a flow of coal to supplement the quantity derived from the coal refuse banks. This would serve the dual purpose of insuring back-up supplies in the ovent of intelluptlons as weli as developing sources of supily when the banks are finally depleted.

Early analyses indicate that the methannt plant and one of the preparation plants would be in the same WilkesBarre Pittston area. The locations of the other three will not be finalized, however, the greatest distance from the Willkes-Barre area, one of the principal areas studies, to any 
bank concentration point in the anthracite region does not exceed 60 miles. This would be the greatest distance over. $19,25,26,27$

which the prepared coal would be hauled.

The demand for automobile fuel in the anthracite.

region is sufficient to use the complete output from a 5000 ton per day methanol plant. In addition, there are a: substantail number of combustion turbines in regional, public utility power plants that in the foreseeable future may incorporate the capability to use this fuel. In view of this... local demand, it is expected that economies of distribution will develop since bulk distribution plants would be reduced. 
COAL SOURCES

The two principal sources of anthracite coal which can supply feed stock for large quantities of methanol are the coal mines and the coal refuse banks that have resulted from mining.

The coal mining activities in the U.S. developed historically with the nation's growth. The fortuitous early discovery of anthracite in eastern Pennsylvania and lts commercial use beginning in 1803 provided the major source of energy for over 100 years. It resulted in an industry which at its peak employed over 180,000 workers. Later discoveries of bituminous coal in western Pennsylvania, Ohio, Maryland, Virginia, and West Virginia resulted in the expansion of the industry into the southwestern Appalachian region accompanied by the newer techniques of strip mining. In more recent times as the country expanded wectward, mines were opened in Illinois (1875), Colorado (1864), Utah (1870), Wyoming (1870), Montana (1890), and New Mexico (1882). However, no significant production other than in Colorado and New Mexico developed in the west before 1900 which was approximately the beginning of the railroad and smelter booms.

The early mines (prior to 60 years) were primarily deep mines as the large earthmoving techniques for the economic removal of overhurien werc not ill existence. To date, in many western states the total cumulative production of underground mines continues to exceed that of surface mining. 
Colorado, for example, at its surface coal mines has produced only 33 million tons in its entire history out of a total of 596 million tons mined. Illinois has produced only 800 million tons from surface mines out of a total of 4 billion tons extracted since $10,11,12$

'the methods of underground mining involve sinking a shaft or tunnel to the location of the coal seam while simultaneously removing the rock and dirt associated with the operation. This so-called tunnel rock and dirt in past years have been deposited in piles or banks at the surface. This refuse for the most part contains little or no coal. In areas where the coal occurs with steep-pitching slopes such as the Pennsylvania anthracite regions, the mining process generally necessitates bringing to the surface all material that is mined.

In the early days of the industry little attention was given to the efficient recovery of coal. Only first mining was done. In the anthracite coal regions the room and pillar system was used extensively. Long gangways were driven and rooms were turned off and worked to their limit. Heavy charges of explosives were used in driving these chambers which resulted in large quantities of fine sized coal being produced and discarded. In the past this was not a serious economic problem as coal was not as valuable as it is currently. More recently it has been recognized that the smaller sizes for which there had been little demand must 
carry part of. the cost of mining the more marketable larger sizes. . Consequențly, efforts were directed not only on recovering slabs off the remaining pillars but also the entire pillar, if practical. Large percentages of lump coal were obtained by these means. In addition, mining methods were modified to produce larger rooms with long faces which resulted in fewer tight corners and less explosives with a consequent reduction in small size coal produced. However, this system of mining requires back filling in order to support the roof. Consequently, minịng refuse was used which would $1,2,13,18$

otherwise be deposited above ground.

There were other. factors involved in underground mining which also contributed to the fracturing.and degradation of coal and the resultant lack of marketability of part of 18

the total production. Numerous transfers of the cual by hand, by corveyurs and by mine car tend to fracture the coal. The use of drag scrapers also contribute. All of this activity produces a milling action which tends to crack, break, and crush larger pieces of coal into fine sized coal. Much of the original coal ends up as discarded refuse. 22,24

Surface mining in former years was confined to coal that lies near the surface where the overburden is thin. The refuse produced consists of surface rock and earth. Little or no degrading of the coal was produced as it was removed by steam shovels and loaded into cars for transportation to the coal preparation plant or for use directly. 
In general, in order to market coal, it must be cleaned and screened to produce a saleable product: The so-called preparation of coal has evolved from the manual process of separating coal from slate, laminated coal, and underground rock in the anthracite mines. For many years coal was broken" manually into sizes suitable for the market; run through screens for sizing, and the finer material discarded since there was no market for fine sizes. By 1844 a roller crusher was invented and incorporated into a coal breaker plant which could crush and screen 200 tons per day. For some 50 years thereafter, little attention was given to preventing unnecessary breakage of coal during preparation. It was not until about 1900 that the demand for anthracite coals of specific and uniform size developed and it became desirable for the operators to produce sized coal with a minimum of breakage. Since that time little underground separation of coal from slate and rock was performed. The entire mined material, thereafter; was processed through the so-called coal breaker. (The breaker's function was not to "break" the coal but to obtain the largest quantity of the various sizes of clean coal with smallest amount of breakage.)

The process of coal mining and preparation produces. $37,38,39$

large quantities of refuse. Approximately 32 b111ion tons of bituminous and lignite coals and 8 billion tons of anthracite have been produced in the U.S. since the earliest records 23

were maintained. In the anthracite fields of Pennsylvania 
from which virtually all the anthracite has been obtained in the U.S., several studies have shown that approximately 1.1 billion tons ( 1.0 billion cubic yards) of refuse have been deposited in piles or banks. Other studies have indicated that in the eastern coal fields (bituminous and anthracite), there. has accumulated 3000 to 5000 sizeable active and abandoned waste piles and silt impoundment ponds which total over 3 billion tons of coal mining refuse. Although strip mining has contributed to the problem of overburden removal and replacement, this refuse is not a coal containing material of sizeable proportions. The coal refuse piles and banks are predominantly the result of underground mining. The significance of the latter is substantial since there have been some 28 billion tons of coal extracted from underground mines while only 4.2 hillion tona have been surtace mined from the bituminous fields since 1866. In the anthracite regiuls, on $l y \bar{y} U .4$ billion tons have been strip mined since $1830^{3}$

In the early days of the industry practically all the coal was prepared dry 2 . The fine-sized material and any other non-marketable sizes were deposited in the vieillily of the breaker along with the waste material in large piles known as culm banks. The older banks contained from $50 \%$ to 80.8 coal in an accumulation of rock, dirt, and slate. Later banks laid down in the early 1900's contained about $20 \%$ to $60 \%$ coal. Over the past 75 years the culm banks have been 
reworked and. for the most part are non-existent or are being held by public utility power companies.

In later years with the use of wet preparation of coal, a fine size coal (silt) was carried out of the breaker and deposited in a so-called silt bank or silt pond. The latter was a later development which grew out of the interest of the coal operators in retaining the silt by building impoundments to retain the water until the silt settled out. As the water seeped out of these ponds, the remaining material was a deposit of high percentage coal.

Over a period of years, processes were developed in coal breaker operations for separating coal and other impurities which depend on differences in specific gravity between coal and its impurities. Using a method generally known as the "heavy media process", it was possible, by adjusting the specific gravity of the liquid medium, magnetite, to float one material and have a second material sink in the fluid, thus effecting a separation. By this means the coal could be separated rapidly from impurities and the latter discarded. coal preparation plants were designed using this technique that could process 1000 tons per hour and as high as 17,000 tons per day on a two-shift operation. The refuse from the preparation plant was not completely free of coal but was substantially better than earlier methods of cleaning the 48 coal.

The production of anthracite in Pennsylvania although at a reduced rate compared to former years, continues at a 
substantial level. The production for a number of recent years is shown below for deep mining, strip mining, and from culm, silt and refuse banks.

$$
\text { Anthracite Production }{ }^{4}
$$

\begin{tabular}{|c|c|c|c|}
\hline & Deep Mining & Strip Mining & Banks \\
\hline 1973 & 710,000 tons & $3,280,000$ tons & $2,300,000$ tons \\
\hline 1974 & 690,000 & $2,800,000$ & $2,6 \cap \cap, \cap \cap 0$ \\
\hline 1975 & 630,000 & $2,500,000$ & $2,500,000$ \\
\hline 1976 & 530,000 & $2,900,000$ & 1,$800 ; 000$ \\
\hline 1977 & 500,000 & $2,890,000$ & $1,660,000$ \\
\hline 1978 & 590,000 & $2,960,000$ & $1,480,000$ \\
\hline
\end{tabular}

The production of anthracite is by twenty major companies who account for approximately $80 \%$ of the output. The demonstrated reserve base of anthracite in Ponnsylvania is 7.1 billion tons of which 6.9 billion tons is mineable by underground methods? The remaining identifiable resources of anthracite at less than $3000 \mathrm{ft}$. depth are 18.8 billion tons.

Forecasts by recent investigators estimate that deep mining will return to a level between 1 and 2 million tons per year; strip mining to approximately 5 to 6 million tons; and culm, silt, refuse, and dredge production of 3 million tons annually. 
In summary, underground mining of both anthracite and bituminous coal have produced over the past 100 years large quantities of coal-containing refuse as well as silt-containing water effluent from coal preparation plants. The refuse is composed of rocks, dirt, coal, and various other minerals which are a result of:

a. extraction from the earth in the mining process

b. residual material remaining after the coal pre-: paration process.

The source of the coal in the refuse is from the coal seams and the source of the rock, dirt, and other minerals primarily from areas immediately above and below the seam as well as from material within the seam. The quantity of various materials. in the coal refuse is a function of:

a. the geologic formation of the coal seam.

b. the physical configuration of the seam

c. the mining mothod usad

d. the coal preparation process used

Refuse sites that have existed for many years will. have a higher content of coal than those of recent years. Improved cleaning methods that have been developed have gradually decreased the proportion of coal in the refuse.

Silt impoundment ponds have a high percentage of fine size coal that has accumulated from the coal preparation plant water since the advent of wet coal preparation plants. 
COAL REFUSE

The deposits of coal rếlíl that exist throughout the anthracite and bituminous coal fields offer an excellent source of raw material for conversion to methanol. In the case of anthracite; the accumulations have taken place over 150 years during the mining of some 8 billion tons of coal in a relatively small area of 480 square miles. Several studies have shown, as the result of field surveys, that as recently as 1969 there were over 800 refuse banks estimated to contain close to 1 billion cubic yards of material. Refuse banks have been produced as a result of both underground and strip mining, but on a smaller scale in the case of the latter owing to the substantially lower total tonnage extracted by surface mining and also owing to the difference in the mining methods. On the other hand, a National Acrademy of Sciences study has shown that in all the eastern bituminous fields there are approximately 3 billion tons of coal waste and silt located in an area of about 70,000 square miles. Owing to the geographical concentration of the anthracite refuse, the high percentage of coal in the refuse as well' as the total quantity deposited, and the proximity of this area to a potential demand center, this study will be focused on these coal wastes rather than the scattered material in the eastern bituminous fields. 'l'he eastern bituminous mines, ${ }^{20}$ ót course, continue to produce large quantities of coal refuse as contrasted to the 
anthracite mines which progressively have reduced production of new coal to approximately 3 million tons with half a million tons of coal refuse annually. Listed below àre examples of ${ }^{13}$ several West Virginia and Kentucky bituminous mines with their coal and refuse output.

Name $\quad \begin{array}{ll}\text { Raw Coal } & \text { Preparation } \\ \text { Cleaned } & \text { Plant Refuse }\end{array}$

\begin{tabular}{|c|c|c|}
\hline $\begin{array}{l}\text { Hendrix } \# 22 \\
\text { Jenkins, } \mathrm{KY}\end{array}$ & 4200 tons/day & 765 tons/day \\
\hline $\begin{array}{l}\text { \#27 Mine } \\
\text { Jenkins, KY }\end{array}$ & 4600 tons/day & 1200 tons/day \\
\hline $\begin{array}{l}\text { Idamay Mine \#44 } \\
\text { Barrackville, } \\
\text { West VA } \\
\text { (mine closed) }\end{array}$ & $\begin{array}{l}50 \text { million tons } \\
\text { (life of the } \\
\text { mine) }\end{array}$ & $\begin{array}{l}8 \text { million tons } \\
\text { (life of the } \\
\text { mine) }\end{array}$ \\
\hline
\end{tabular}

In general, approximately $20 \%$ of the coal is lost in the cleaning and sizing preparation process. However some $30 \%$ of all mined bituminous coal is not mechanically cleaned but is shipped directly from the mine to user.

The locations and sizes of over 800 anthracite coal refuse banke are acrirately known through a 1966 survey of the U.S. Bureau of Mines and a later study in 1975 by a private contractor. Also, a 1926 survey by the U.S. Bureau of Mines and the Pennsylvania Geological Survey located, identified the source, and estimated the quantity of material in 300 large culm and silt banks which totaled 500 million tons. In order to determine the potentially available quantities of refuse from which coal could be recovered it is necessary 
to know to what extent additional refuse has been deposited and the degree to which old banks have been reworked.

The anthracite region of Pennsylvania is divided into four fields along geographical lines. They are the Northern, Eastern Middle, Western Middle, and Southern Fields as shown in Figure"2. Known reserves in this region are huge.* The 19.75 study of the anthracite region developed the following estimates for the volumes of refuse material and coal in each of the four coal fields. The investigators used the 1966 survey and.updated it with known data on annual coal production from the reworking of existing banks in order to arrive at a probable life of the coal refuse after 1974, should re-processing of the refuse banks continue. (Table 1).

As of 1974 , it was estimated that $96,578,000$ tons of coal were contained in all hanks ueing cool pescientage that were conservatively estimated to be $15 \%$ in the coal preparation refuse (breaker refuse); $25 \%$ in the silt deposits: and $25 \%$ in the breaker refuse and silt deposit mixed. 'The silt is for the most part $3 / 64$ inch size down to 200 mesh particles. The breaker refuse was derived from processing runof-mine coal in the breakers. A part of this refuse is coal that bypassed the preparation process and the other fractions are coal-rock laminates that were not successfully separated by the heavy media process. Present preparation processes

*

Appendix 1. 


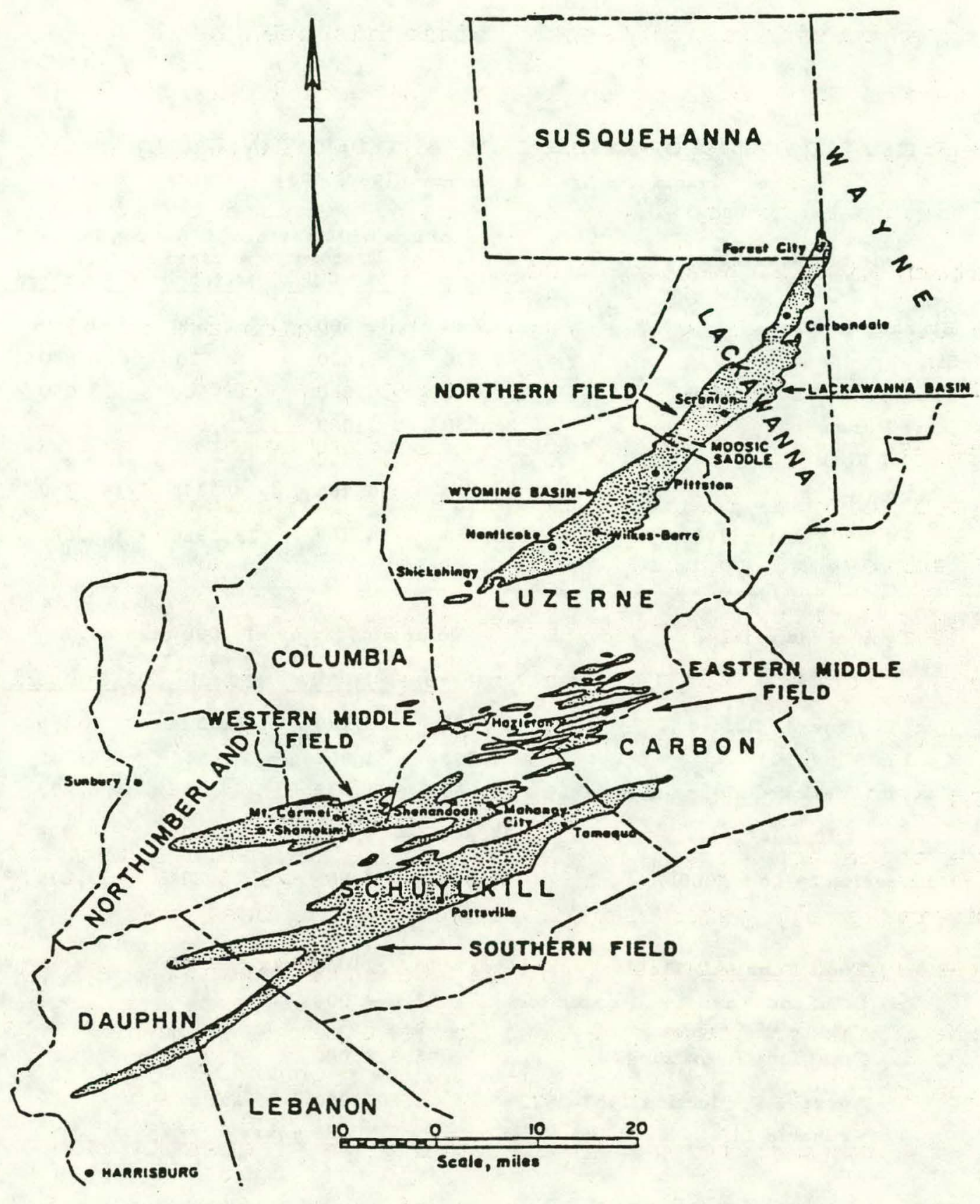

Anthracite Region of Pennsylvania.

Figure 2 . 


\section{Table 1}

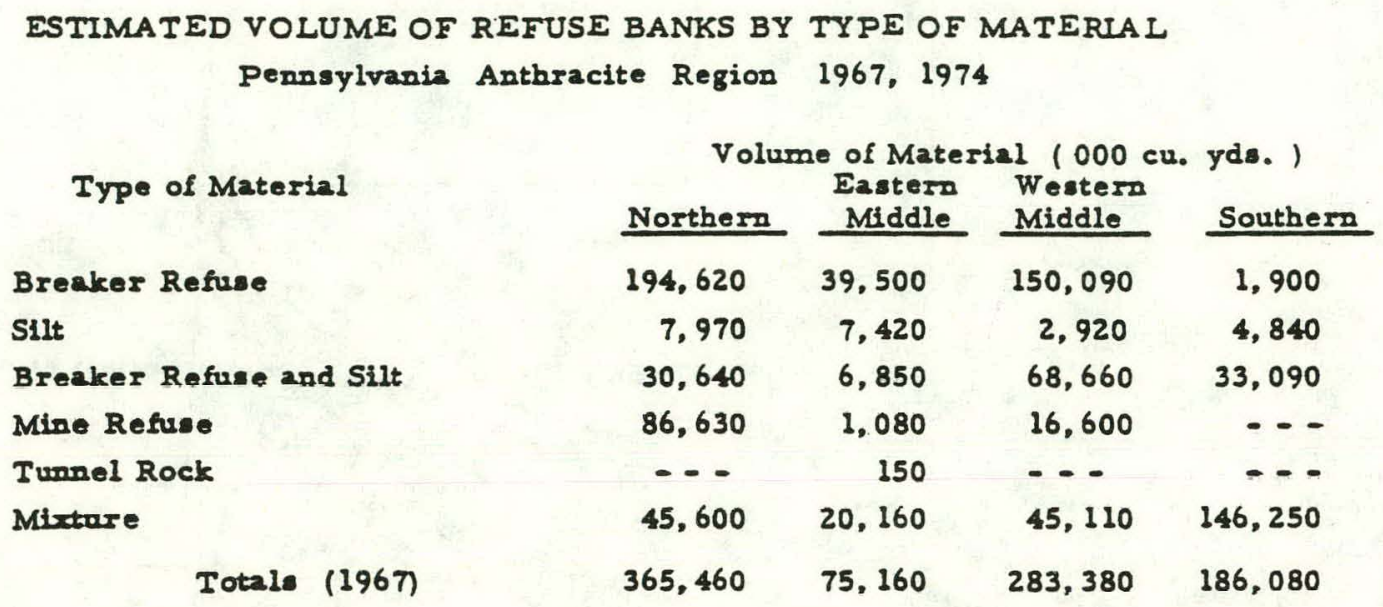

\footnotetext{
Iype of Material

Assumed Percent of Cosl
}

Cosl in Breaker Refuse (15\%)

Çoal in Silt $(25 \%)$

Coal in Breaker Refuse and Silt (25\%)

Iotals

Conversion to Tons (000)

\begin{tabular}{|c|c|c|c|}
\hline $\begin{array}{c}\text { Volu } \\
\text { Northern } \\
\end{array}$ & $\begin{array}{l}\text { Of Mate } \\
\text { Eastern } \\
\text { Middle }\end{array}$ & $\begin{array}{l}\text { Western } \\
\text { Middle }\end{array}$ & Southern \\
\hline 29,193 & 5,940 & 22,514 & 285 \\
\hline 1,993 & 1,855 & 730 & 1,210 \\
\hline 7,660 & 1,713 & 17,165 & 8,273 \\
\hline 38,846 & $y$, buy & 40,409 & 9,768 \\
\hline 47,004 & 11,505 & 48,894 & 11,819 \\
\hline
\end{tabular}

\author{
Total Tons (All Flelds) \\ Bank and Washery Production \\ Since 1966 \\ Total Tons Remaining \\ Average Production 1967-1973 \\ Probable Iife
}

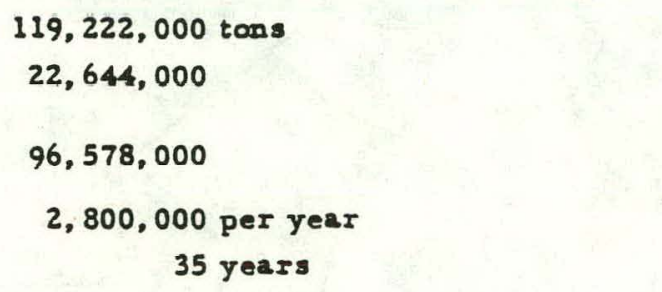

(Data from "Evaluation of Mining Constraints to the Revitalization of Pennsylvaria Anthracite" Berger Associates, Harrisburg, PA Mar. 1975) 
permit approximately 5\% of the coal to pass into refuse. However, the refuse from plants earlier. in this century, as noted previously, could reach as high as $30 \%$ coal. The coal sizes in these banks are predominantly $3 / 16$ inch to 3 inches with some $10 \%$ to $15 \%$ larger than 3 inches.

It should be noted that in order to utilize the coal in the breaker refuse, it must be reprocessed through a coal preparation plant including a crushing stage to break up the laminates. The refuse that results from this second reprocessing in a modern prep plant contains very little useable coal.. The silt refuse, on the other hand, can be used directly without reprocessing if the refuse content is acceptable.

The mine refuse which is generally brought to the surface in mine cars separately from the coal is sometimes dumped with the breaker refuse. This material contains a small amount of coal that would not be recoverable economically. Sizes could range up to large pieces that would be difficult for two men to handile.

The tunnel rock consists of non-coal containing material, namely, rock and dirt that was removed when tunneling took place. It is brought up from the mine separately from the coal but may be deposited with the mine refuse.

The coal requirements for feedstock for a 5000 tons per day coal-to-methanol conversion plant will be approximately 3 million tons annually. Data were collected and tabulated on the larger banks that would be capable of 
supplying a significant part of the coal and would be located sufficiently near each other to minimize transportation costs of the coal to the plant. A frequency distribution of the refuse banks larger than 10,000 cubic yards as a function of size is tabulated below considering only those containing some coal and excluding those banks that are composed only of mine refuse and tunnel rock?

\begin{tabular}{|c|c|c|c|}
\hline \multicolumn{2}{|c|}{$\begin{array}{l}\text { Size } \\
\left(10^{\text {f }} \text { cu. ydus. }\right)\end{array}$} & Number & $\begin{array}{l}\text { Total Quantity of Refuse } \\
\left(10^{6} \text {. cu. yds.) }\right.\end{array}$ \\
\hline .01 to & .90 & 417 & 95.8 \\
\hline .91 to & 1.50 & 71 & 82.4 \\
\hline 1.51 to & 2.50 & 35 & 68.6 \\
\hline 2.51 to & 3.50 & 31 & 92.1 \\
\hline 3.51 to & 4.50 & 23 & 89.1 \\
\hline 4.51 to & 5.50 & 4 & 19.3 \\
\hline 3.51 to & 5.50 & 9 & 55.1 \\
\hline 6.51 to & 7.50 & 8. & 65.6 \\
\hline 7.51 to & 8.50 & 2 & 16.4 \\
\hline 8.51 to & 10.50 & 5 & 49.7 \\
\hline 10.51 to & 15.50 & 5 & 65.1 \\
\hline 15.51 to & 20.50 & 2 & 34.8 \\
\hline Above & 20.50 & 2 & 65.8 \\
\hline & & 614 & 800.1 \\
\hline
\end{tabular}

These 800 million cubic yards of refuse, as was notedearlier, are estimated by investigators to contain approxi- 
mately 1 billion tons of material and about 100 million tons of coal. In order to supply sufficient coal for a 5000 tons per day methanol plant, clusters of banks would be utilized to supply material to a number of preparation plants. A large prep plant will process 1000 tons per hour of material which would yield an estimated 200 tons of coal for gasification. Three such plants operating on two 8-hour shifts, can produce 9600 tons of coal daily (3.5 million tons annually). No single individual coal refuse bank contains as much as 30 million tons of material with the exception of one large site of 110 acres in the Western Middle anthracite ${ }^{17}$ field in the vicinity of Mahanoy City reported to contain 37 million tons. For a 15 year project life involving 12 years of plant operating and a feedstock with average coal content of $17.9 \%$ (a weighted average of the $15 \%$ coal in breaker refuse and $25 \%$ in silt and breaker refuse and silt)

Average coal content

$$
\begin{aligned}
\text { in refuse }= & \left(.15 \times 388 \times 10^{6}+.25 \times 23 \times 10^{6}\right. \\
& \left.+.25 \times 138 \times 10^{6}\right) / 549 \times 10^{6}=17.9 \%,
\end{aligned}
$$

a total refuse bank supply of $\left(12 \times 3 \times 10^{6}\right) / .179=201$ million tons (182 million cubic yards) is required. This represents approximately $25 \%$ of the total refuse bank inventory excluding the mine refuse and tunnel rock.

The geographical distribution of the refuse banks is shown in Figure 3. It can readily be seen that they cluster about the major cities in each of the four fields. Because 
coal mining was the principal industry in the area for many years, most of the population lived close to the mines. The largest number of banks both in number and total volume occur in the Northern field. Furthermore, the groups of banks are well-clustered in that field which would minimize the transportation of material to any prospective preparation and gasification facility nearby. Figure 4 shows an expanded display of the locations of 260 refuse banks in a 22 mile section between Wilkes-Barre and Carbondalệ.,52

A number of banks in this section that were well grouped were analyzed in more detail as to size, location, and operational difficulties relative to reworking for coal extraction and gasification. Banks \#142 through \#147 plus \#149, \#151, and \#156 which are located in the area between w1lkes-Barre and Pittston as shown in Fiqure 5 were selected. The approximate size of each of these banks.is:

$\begin{array}{rr}\# 142 & 1,610,000 \text { cubic yards } \\ \# 143 & 5,600,000 \\ \# 144 & 2,930,000 \\ \# 145 & 180,000 \\ \# 146 & 90,000 \\ \# 147 & 990,000 \\ \# 149 & 330,000 \\ \# 151 & 1,070,000 \\ \# 156 & 280,000\end{array}$




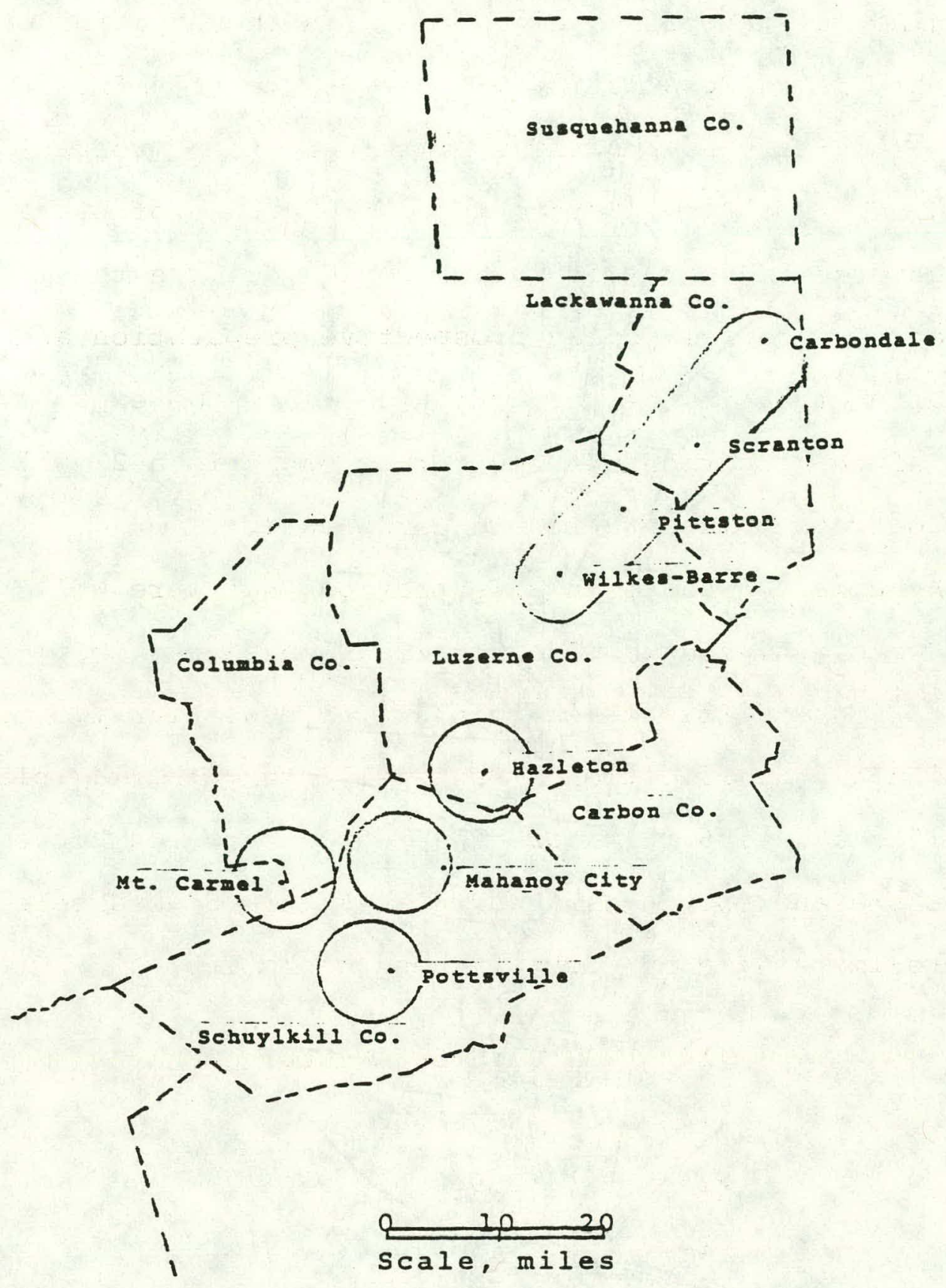

Figure 3 Anthracite Region of Pennsylvania Major Clusters of Refuse Banks 


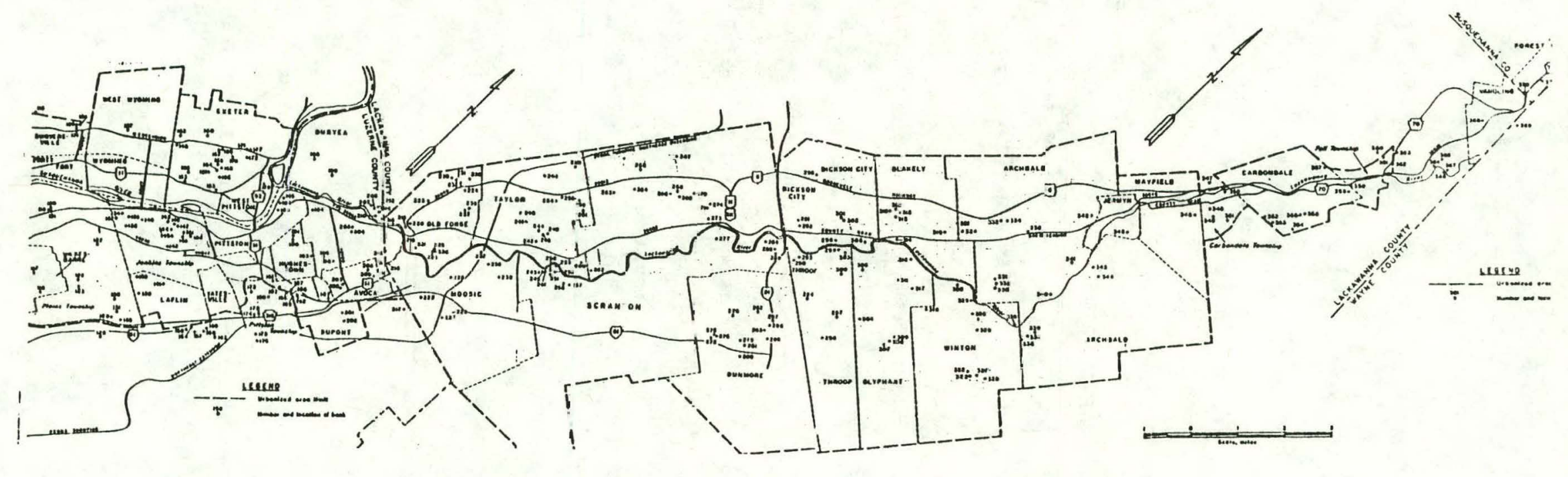

Figure 4. 


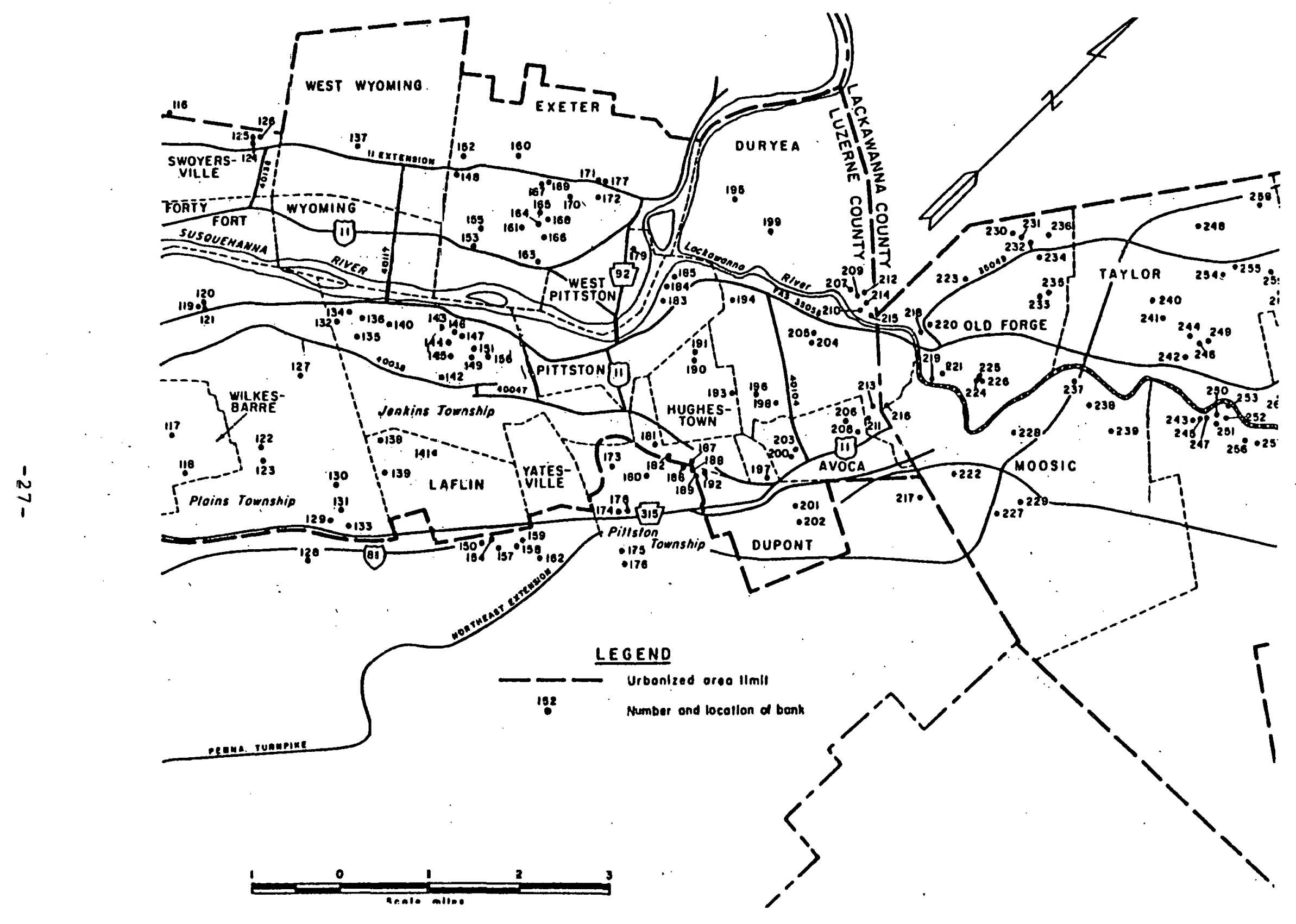

Figure 5 . 
All of these banks are located on about 100 acres and contain from $10 \%$ to approximately $20 \%$ coal depending upon the time the deposits were laid down. The site is near the susquehanna River at the location of the Ewen colliery operated early in this century by the Pennsylvania Coal Company. The total estimated coal that is recoverable is 1.5 million tons. In a demonstration effort that is focused on determining if anthracite refuse can be cleaned and marketed economically, the U.S. Department of the Interior is undertaking a project jointly with a private company to design, construct, and operate a 350 tons per day preparation plant to rework refuse from a number of the above banks at the Ewen location. The plant is expected to produce 35 tons per hour of small sizc coal and will operate two 8-hour shifts daily.

In addition to the 1.5 million tons of coal adjarent to this demonstration plant, there are an estimated $226,000,000$ tons of coal refuse in the remaining banks of the group of 260 . These banks contain sufficient coal to meet the total gasification feedstock needs. The average banks is located at a distance of 11 miles from the site of the nine banks selected in the Wilkes-Barre-Pittson area. 
COAL GASIFICATION

Gasification of anthracite coal has been investigated both at laboratory scale and in pilot plants at a number of locations throughout the world. The U.S. Bureau of Mines has conducted tests at Pittsburgh, Pennsylvania, in Iurgi type equipment with generator sizes ranging from 4 inches to 13.5 inches diameter. The 4-inch tests provided data which indicated that the anthracite gasification was satisfactory Owing to operating problems with this small equipment, the gasifier was increased in size and tests were run satisfactorily using anthracite Buckwheat No. 3 and No. 4.

Pilot plant runs were made in Holten, Germany?, with several British coals and in Birming gham, England, with a Welsh anthracite to study the influence of volatile matter upon the product gas, and the reactivity of coal toward steam under different operating conditions obtained by varying the steam to oxygen ratio, pressure, and rates of gasification. The results showed that anthracite could be used successfully as a replacement for bituminous coal but with lower gasification rates and higher oxygen requirements. The' volume of $\mathrm{CO}+\mathrm{H}_{2}$ was higher than for bituminous and the $\mathrm{CH}_{4}$ also was lower in the gas produced from anthracile. For a conversion process to methanol, high carbon monoxide and hydrogen is desirable and low methane is also desirable. A number of tests have been conducted using Korean anthracite in a Lurgi generalur in Ilolton, Germany. Results 
were encouraging using an anthracite'run-of-mine coal with 23.2\% ash and also with a washed and screened coal containing $14.5 \%$ ash. As was expected, the consumption of oxygen was lower for the prepared coal $(291 \mathrm{cu}$. ft./1000 cu. ft. of clean gas) than for the run of the mine anthracite $(333 \mathrm{cu}$. ft./1000 cu. ft. of clean gas) owing to lower ash content.

$\therefore$ By virtue of an increasing demand for natural gas and the need to locate additional or alternate sources, the U.S. Bureau of Mines arranged to conduct a number of demonstration tests in Dorsten, Germany, to gasify two sizes of Pennsylvaria anthracite in commercial-size Lurgi gasifiers. A Chestnut size with 25\% ash and a Rice (\#2 Buck-wheat) mixed with \#1 Buckwheat with 15\% ash were selected.* These coals "are non-caking and have a high ash-softening temperature whlich the Lurgi gasifier requires. Both were obtained from the Northern field of Pennsylvania. The coal was stored in piles in the U.S. prior to shipment. Subsequently, it was transported by rail to Philadelphia, by ocean vessel to Rotterdam harbor, by barge to a German mining company, and by rail to the Lurgi test facility. The anthracite was handled seven times en route including three times by clamshell loaders, once by frontend loaders, and once by a belt conveyor. These multiple handings resulted in some degradation of the coal which appeared to produce no major problems in the gasifier.

See Appendix 2, Standard Anthracite Specifications 
These tests were run generally for approximately 24 hours at coal feed rates of 5 to 6 tons per hour. One of the primary goals was to establish to what extent the steamoxygen ratio could be reduced without affecting the operation since the excess steam is a major source of inefficiency in the Lurgi gasifier. Since the installation could not be dedicated exclusively to the anthracite tests owing to ongoing commitments, the tests were not as comprehensive as those that could have been conducted otherwise.

A series of five tests were made on successive days

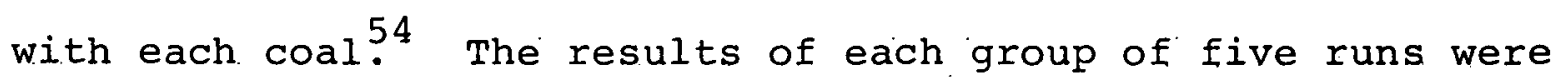
averaged. The results are contained in Table 2 .

No data were obtained on the quantity of residual ash or for the combustible material remaining in the ash in these tests. Because of the method used in disposing of the ash at the Dorsten facility, it was not practical to secure this information. The ash from this gasifier was mingled on a conveyor with ash from all plant units as it was transported from the facility.

Among the other available gasifiers that appear to be applicable to the gasification of anthracite coal is that developed by Texaco Inc. some 25 years ago. This commercially proven process was originally conceived for producing synthesis gas from hydrocarbon feedstock such as residuals resulting from petroleum refining processes and from tars and pitches. Since 1953, over 75 plants have been constructed 
Table 2

Test Results with Anthracite in Lurgi Gasifier

\section{Chestnut}

Duration

Coal (DIY)

24.35 hrs.

Coal (Ash free)

oxygen

15,547 lbs./hr

$11 !, 3291 \mathrm{bs} . / \mathrm{hr}$

79,510 cu.ft ihr.

Steam (high pressure)

Gas Produced 430,629 cu.ft./hr.

$\mathrm{CO}+\mathrm{H}_{2}$ 287,941 cu.ft./hr.

Temperature (exit) $1016^{\circ} \mathrm{B}$.

Pressure (Generator) 23 atmospheres

Gas composition

$\mathrm{CO}_{2}$

$\mathrm{C}_{\mathbf{n}} \mathrm{H} \mathbf{m}$

co

$\mathrm{H}_{2}$

$\mathrm{CH}_{4}$

$\mathrm{N}_{2}$

Ratios per $1000 \mathrm{cu} . f t$. of gas

coal (Dry) $36.11 \mathrm{bs}$.

Coal (Ash free)

26.2 1bs.

oxygen (Pure)

steam
26.08

๑. 2

26.3

40.6

5.4

1.5
Rice-Buckwheat

$$
\begin{aligned}
& 25.92 \text { hrs. } \\
& 15,147 \text { lbs./hr. } \\
& 12,236 \text { lbs./hr. } \\
& 83,612 \text { cu.ft./hr. } \\
& 26,970 \text { lbs./hr. } \\
& 500,387 \text { cu.ft./hr. } \\
& 338,003 \text { cu.ft./hr. } \\
& 1035^{\circ} \mathrm{F} \text {. } \\
& 24.98 \\
& 0.2 \\
& 26.9 \\
& 40.6 \\
& 5.8 \\
& 1.6
\end{aligned}
$$

$30.31 \mathrm{bs}$.

$24.41 \mathrm{bs}$.

$167.0 \mathrm{cu} .1 \mathrm{t}$.

$53.91 \mathrm{hs}$. 
using this pressurized process to produce over a billion cubic feet per day of low or medium Btu synthesis gas. More recently Texaco has been developing the gasifier to make it suitable for coal gasification.

As planned for coal gasification, the gasifier is a vertical pressure vessel consisting of a steel shell with a refractory liner. Pulverized coal is partially oxidized with steam and oxygen in this reactor vessel. The resulting gases and molten slag flow downward through a water spray chamber and a slag quench bath. Since the temperature is high enough to liquefy the ash, quenching is needed so that the gas can be handled in steel equipment without benefit of liners. The pulverized coal feedstock is slurried with water when pumped to the gasifier. Consequently, the moisture content of the feed coal is not restrictive in the process.

This pressurized, entrained bed slagging gasifier is capahle nf handling a wide variety of caking and non-caking coals. Currently, tests have been run on a broad range of lignites and bituminous coals with satisfactory results. A typical gas composition that results from a coal (Illinois \#6 bituminous of 13,150 Btu/1b.) is:

Gas Composition

$$
\text { Mole : } \quad \mathrm{CO}_{2} \quad 20.8
$$




$\begin{array}{ll}\mathrm{CO} & 37.6 \\ \mathrm{H}_{2} & 39.0 \\ \mathrm{CH}_{4} & 0.5 \\ \mathrm{H}_{2} \mathrm{~S} & 1.5 \\ \mathrm{~N}_{2} & 0.6\end{array}$

Pressure (Gasifier)

Temperature (Gasifier exit)
20 to 80 atmospheres $400^{\circ}$. to $500^{\circ} \mathrm{F}$.

More recently, owing to encouraging results, 'Texaco has planned a scale-up of their pilot plant operations to a full-scale development involving a 1000 tons per day coal gasification plant at Daggett, California. This operation will use a western subbituminous coal and will demonstrate the acceptability of both performance and emission shararteristles using a gasified coal to fire a 65 megawatts steam boiler of Southern California Edison Company. The program together with a second phase involving a combined-cycle power generation unit is funded at $\$ 300$ million and is scheduled to be operational in late 1984 .

Although the Texaco gasifier has not been tested with anthracite coals, its capability to handle a broad array of feedstocks is encouraging from the standpoint of utilizing anthracite. The refuse banks, throughout the anthracite region, may prove in a detailed investigation to contain a wide spectrum of anthracites which would indicate that a gasifier that can handle a broad selection of coal feeds 
would be desirable. If difficulties develop, it appears that they will center around the fact that a higher operating temperature is needed in order to get above the fusion temperature of anthracite ash to produce a slag. However, this may present problems particularly in regard to such items as the refractory liner's ability to stand the higher temperatures and also the efficiency of the overall process. In the latter case more coal would be consumed in reaching. an elevated temperature. A conclusive determination as to the feasibility of using this gasifier would have to await tests by Texaco of some specific anthracite coals! 92 
DEḾAND

The 480 square miles of the Pennsylvania anthracite region contains a population (1978) of approximately 750,000 or $6.4 \%$ of the state. The 11.3 million inhabitants of Pennsylvania, in 1978, operated 6.9 million autos which consumed 4,800 million gallons of gasoline during the year, or, approximately 13 million gallons daily ${ }^{68}$ This consumption is derived from the national average of 685 gallons per auto per year. For the anthracite region, on a comparable basis, the gasoline consumption is estimated at 300 million gallons annually or 820,000 gallons (2400 tons) daily. On an equivalent energy basis, this 2400 tons of gasoline is equal to 5280 tons of methanol. Consequently, the inhabitants of this anthracite coal region have a potential demand, within this 480 square mile area, of $96 \%$ of the production capacity of a 5000 tons per day methanol plant assuming that a vehicle tuel of $100 \%$ methanol would be utilized. If blended with gasoline, any methariol consumed, either $100 \%$ or as a blend with gasoline, would have a net effect of reducing the demand or requirement for gasoline or other petroleum based fuel.

In addition to the demand for methanol for highway vehicles in this region, there is the potential demand for liquid fuel for public utility combustion turbines that are used to meet peak electric power demands. The anthracite region is centralized in the service area of the Pennsylvania 


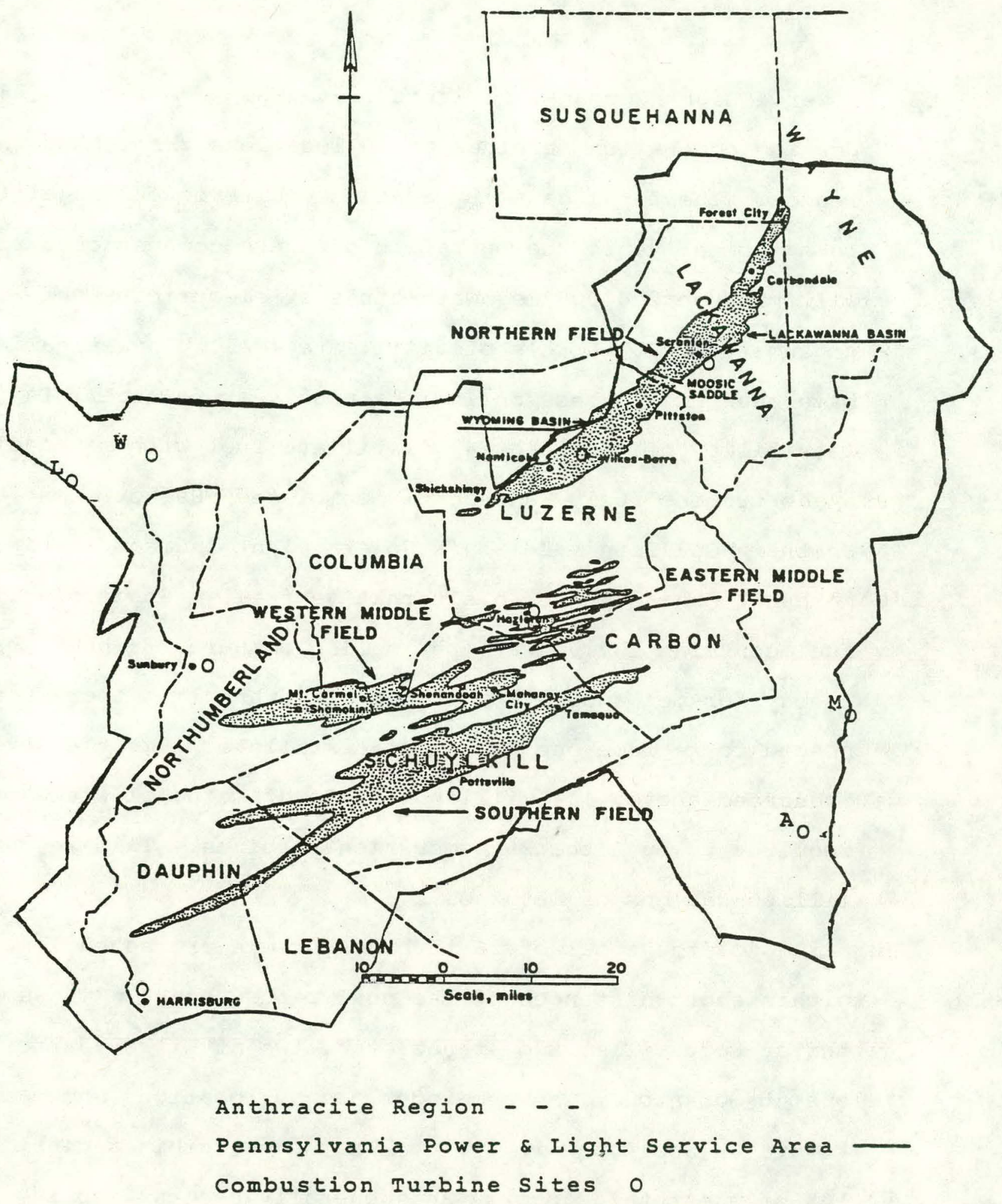

Lock Haven I, Williamsport W, Martins Creek M, Allentown A

Figure 6 . 
Power \& Light Company. (Figure 66,67 This company has 26 peaking combustion turbines at 10 locations throughout the region. The total capacity of these units is 487 megawatts. In a typical year, the operation of these combustion turbines will produce 270,000 megawatt-hours of electricity and will consume 700,000 barrels of distillate fuel. Investigations have been in progress during the past year to ascertain the feasibility of replacing \#2 distillate fuel with methanol as a gas turbine fuel. A recently completed 500 hour test at Southern California Edison's Goleta plant indicates that methanol can serve as an alternative fuel. ${ }^{62}$ Since distillate fuel contains 137,000 Btu per gallon compared to half that energy for methanol, two gallons of methanol is therefore needed to replace one gallon of distillate. For the period indicated above, 1.4 million barrels of methanol would be required to fuel the 26 combustion turbines. This is 59 million gallons of methanol.

of the total of 26 turbines, there are seven located within short distances of the coal refuse banks. These are: two at Pottsville, two at Hazleton, two at Wilkes-Barre, and one at scranton. The remainder are at locations shown in Figure 6 (See Appendix 3) . $^{6,67}$ The seven turbines constitute $16 \%$ of the total capacity and generally account for $16 \%$ of total annual fuel consumption. If distillate fuel were replaced by methanol in these seven turbines, there would be an annual demand for approximately 10 million gallons of methanol. 
The remaining 19 turbines are at six locations which average 65 miles from the center of the Northern anthracite field. There annual demand would be approximately 40 million gallons of methanol for an average year in which distillate would be totally replaced by the methanol fuel.

In summary, the Pennsylvania anthracite region has sufficient potential demand primarily through automobile fuel needs and secondarily through public utility combustion turbine fuel requirements that the region could readily reach a total annual demand of 5000 tons per day of methanol. 
$\cos \mathrm{TS}$

In order to evaluate the costs associated with constructing, financing, and operating a 5000 ton per day coal conversion to methanol plant, a review of current coal gasification projects and processes as well as proposed engineering designs was' máde! 108,109 Among those considered were projects by Badger Plants Incl4, Mobil oit' ${ }^{15}$ Company, C.F. Braun \& Company, and the Atomic Energy Commiseion. In dulttion two lignite gasification projects conducted by American Natural Resources Inc. ${ }^{99}$ and Wentworth Brothers Inc. ${ }^{102}$ were reviewed.

The overall cost of a methanol from coal plant and ultimately the cost of the methanol is primarily a function of the following factors:

- Price of Coal

- Plant Site \& Construction Cost

- Capital structure

- Return of Equity

- Interest on Money

- Plant Life

- Bond Life

- Construction Period

- Inflation

Within each of the above ten factors, there are individual subfactors and costs which clearly influence the cost of the product. Among these factors, tradeoffs are 
necessary in order to arrive at a feasible overall system which will perform from an engineering standpoint while producing an economically acceptable product. For example, a low cost coal might be available but its physical characteristics are such that a large quantity of fines are produced in the handling which makes the material unacceptable as feedstock to gasifiers requiring close tolerances on coal input.

There are also technical aspects of gasification which have not been considered in this study of cost determination. In general, the major producers of operational gasifiers such as Lurgi,' Wínkler, and Koppers-Totzek have second and third generation equipment and modifications in process which would require detailed analyses beyond the scope of this study in order to determine costs. Data has primarily been used only from first generation equipment.

It also must be recognized that to date no 5000 tons per day methanol fiuil coal plant has been constructed. The largest methanol from natural gas plant currently is of the order of 2000. tons per day. Consequently, all cost studies by investigators of both the coal gasifiers and the methanol synthesis units at these scales have as yet to be substantiated with plant construction and operation.

A 125 billion Btu per day output coal gasification plant was selected to ascertain costs since this was the approximate size of a 5000 tons per day methanol operation. In addition, a sufficient number of studies had been performed 
by such companies as Lurgi, Winkler, Koppers-Totzek, Davy

Powergás, the U.S. Atomic Energy Commission, Wentworth, Texaco 33

and others at this scale concluding that a high degee of

integrity exists for the numbers developed in various modules of the system. A Winkler gasifier which can handle $3 / 8$ " size coal as input was considered. This gasifier does not require drying of the coal, nor pulverizing, nor specific screening. Amnng the other favordule characteristics which contributed to its selection for use with anthracite obtained from coal bank refuse are:

- Variations in ash content of the coal are not critical

- It is easy to start up and shut down

- Either oxygen or air can be used

- The gasifier has no muviny parts; hence there are fewers parts to produce problems

- The gasifier has a wide range of operating rates from maximum to minimum points

- The gasifier is a vertical, refractory lined vessel which potentially can withstand the higher operating temperature of the anthracite

- The liquid waste effluents from the system can be handled at the plant site by known technology that is environmentally arseptablc

- The gas produced has only parts per million of contaminants such as $\mathrm{NH}_{3}$ and $\mathrm{HCN}$.

The Winkler gasifier 77 will consume about 8500 tons of coal per day. The Anjomar project, to demonstrate the preparation of coal from coal refuse, estimates they can produce the coal for the market at a cost of $\$ 17.00$ per ton. This cost will be used in developing the operating costs for 
the Winkler gasifier system. Since many of the individual items are older costs, they will be scaled up using an inflation factor of 1.40 obtained from Figure 7 on the construction cost index changes between 1974 and $1979^{103}$

$$
\text { CAPITAL COST - } 125 \text { Billion Btu/day Plant }
$$

Coal Preparation and Storage

Gasification

Waste Heat Recovery and Gas Clean Up

Gas Treatment, Drying, and Compression

Gas Shift Conversion

Methanol Synthesis

Sulfur Recovery

oxygen Plant

offsite Boiler and Plant Utilities

Wasțe Water Treatment

Plant Facilities

TOTAL

Contingencies

GRAND TOTAL

77

Operating costs other than coal consist of the following in the areas of utilities, maintenance, supervision, administration, taxes, insurance, and general overhead:

- Operating labor at $\$ 29,000$ per manyear including fringe benefits

- Maintenance is divided 60 for for labor and $40 \%$ for materials
$\$ 9.2 \times 10^{6}$

35.0

21.0

83.0

39.0

53.0

11.0

63.0

50.0

9.8

11.0

$\overline{385.0 \times 10^{6}}$

43.0

$\$ 428.0 \times 10^{6}$ 


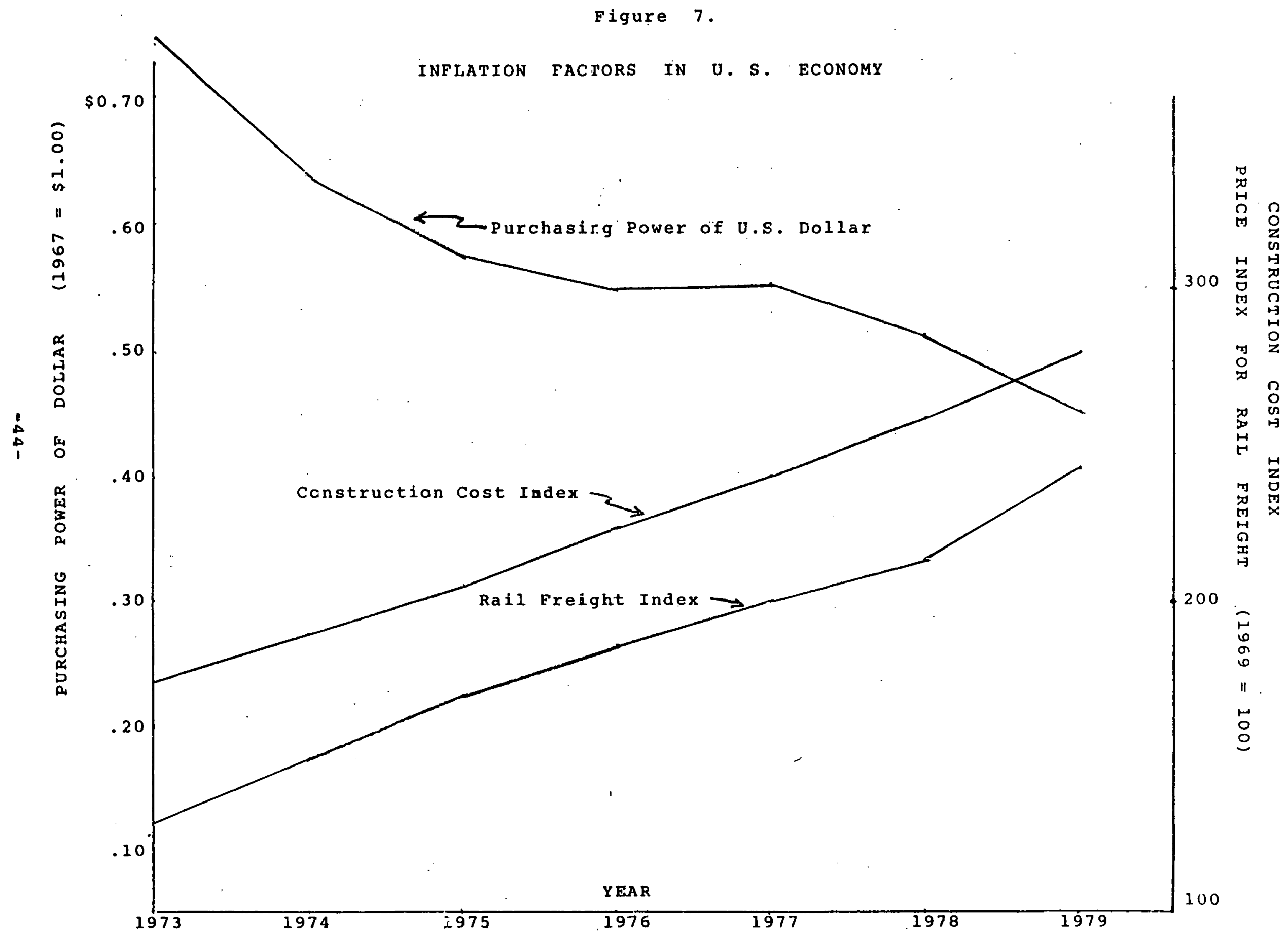


- Electricity at 4.2 cents per kilowatt-hour

- Chemicals at $\$ 5600$ per day on stream

- Supervision is $20 \%$ of operating and maintenance labor

- General and administrative overhead is $60 \%$ of labor and supervision

- Supplies are $30 \%$ of operating labor plus maintenancè supplies

- Taxes and insurance are $2.7 \%$ of capital cost

This plant is assumed to operate at a $90 \%$ service factor or a total of 330 days per year. At 8500 tons of coal per day, the plant will consume about 2.8 million tons annually. In the following tabulation of the annual operating costs, the coallcost will be segregated from the total of all other operating costs.

ANNUAL OPERATING COSTS - 125 Billion Btu/day Plañ

Coal 2.8 million tons a $\$ 17.00$

$\$ 47 \times 10^{6}$

Other Operating Costs

\begin{tabular}{|c|c|c|}
\hline $\begin{array}{l}\text { Electricity } \\
\text { Chemicals } \\
\text { Labor }\end{array}$ & & $\begin{array}{r}2.2 \times 1.0^{6} \\
1.8 \\
12.3\end{array}$ \\
\hline $\begin{array}{l}\text { Operating } \\
\text { Maintenance } \\
\text { Supervision }\end{array}$ & $\begin{array}{l}3.7 \\
6.5 \\
2.1\end{array}$ & \\
\hline $\begin{array}{l}\text { General \& Adm } \\
\text { head }\end{array}$ & iist. nver- & 7.4 \\
\hline Supplies & & 5.5 \\
\hline $\begin{array}{l}\text { Operating } \\
\text { Maintenance }\end{array}$ & $\begin{array}{l}1.2 \\
4.3\end{array}$ & \\
\hline \multicolumn{2}{|c|}{$\begin{array}{c}\text { Taxes and Insurance } \\
\text { TOTAL }\end{array}$} & $\frac{11.6}{\$ 40.8 \times 1}$ \\
\hline
\end{tabular}


The total capital requirements for constructing and starting up this plant were determined and are tabulated in the following table again escalating the costs by the factor of 1.4 used earlier in the capital cost determination.

TOTAL CAPITAL REQUIREMENTS - 125 Billion Btu/day Plant

Onsite Facilities

Offsite Facilities

Subtotal

Contingensies

Total P̈lant Investment

Catalyst charge

Allowance for funds during construction

Start up costs

Working capital

Total Capital Requirèments
$\$ 294 \times 10^{6}$

$91 \times 10^{6}$

\begin{tabular}{c}
$\begin{array}{r}385 \times 106 \\
43 \times 10^{6}\end{array}$ \\
\hline $428 \times 10^{6}$ \\
.44 \\
91.50 \\
20.20 \\
23.00 \\
$\$ 563.00 \times 10^{6}$
\end{tabular}

The average eost of the output of the plant (per million Btu) will be calculated ucing the Utility Financing Methud. 'I'his method involves using a 20 year project life, 5\% per year depreciation on the total capital requirements but excluding the working capital and ucco a 48 응 Federal income tax rate. In the following tabulation, the ralculations are performed using $15 \%$ annual return on equity, $9 \%$ annual interest on debt, the debt fraction is at $75 \%$, and the return on the rate base is $.09 \%(.75)+.15 \%(1-.75)=$ $10.5 \%$ per year. 
CALCULATIONS OF COST OF PLANT OUTPUT - 125 Billion Btu/day Plant

\section{Utility Financing Method}

20 year project life

5\% per year straight line depreciation on total capital requirements excluding working capital

$48 \%$ Federal income tax rate

C=Total Capital Requirements

$=\$ 563.0 \times 10^{6}$

W=Working Capital

$=\$ 23.0$

$\mathrm{L}=$ Total coal cost per Year

$=\$ 47.0$

$\mathrm{N}=$ Total other Operating Costs

$=\$ 40.8$

$G=$ Annual Output of the Plant

$=40.7 \times 10^{12}$ Btu

$\mathrm{d}=$ Debt Fraction

$=.75$

$i=$ Interest on Debt

= 9\% per year

$r=$ Return on Equity

$=15 \%$ per year

$\mathrm{p}=$ Return on Rate Base

$=10.5 \%$ per year

Average Cost per million Btu of

Plant Output

$$
=L+N+.05(C-W)+.005\left(p+\frac{48}{52}(1-d) r\right)(C+W)
$$

G

$=47+40.8+.05(563-23.0)+.005\left(10.5+\frac{48}{52}(.25) 15\right)(563+23.0)$

$$
40.7
$$

$$
=\frac{47+40.8+27.0+41}{40.7}
$$

$=\$ 3.84$

This $\$ 3.84$ per million Btu consists of $\$ 1.16$ in cudl cost, $\$ 1.00$ in other operating costs, and $\$ 1.68$ in charges to the capital invested. 
In addition to the operating costs of the plant some costs must be recognized for the coal that has to be hauled to the gasifier plant from outlying areas. By updating Bethlehem Mines' experience on the cost of hauling preparation plant refuse to disposal sites, short hauls could be as costly as $\$ 0.40$ per ton-mile or as low as $\$ 0.20$. For major shipments in which rail would be used, a cost as low as $\$ 0.07$ per ton-mile may be attained. The entire anthracite region ia well llnked by rail as Figure 8 indicates. This, of course, is an outgrowth of the fact that the coal mines and the railroads in these regions were at one time virtually owned by the same companies since coal moved only economically by rail before the introduction of large trucks.

In terms of an assumed typical distance from wilkesBarre for a remote refuse bank, a 60 mile freight haul would add $\$ 24.00$ maximum or $\$ 12.00$ minimum to the list of a ton of Lual. 'l'his is equivalent to adding about $\$ 1.66$ or at minimum $\$ 0.84$ to the cost per million Btu.

In summary, Llie total cost por million Btu of luethanol at the plant gate could be as low as $\$ 3.34$ or as high as $\$ 5.50$ if the coal is hauled from a distance of 60 miles. 


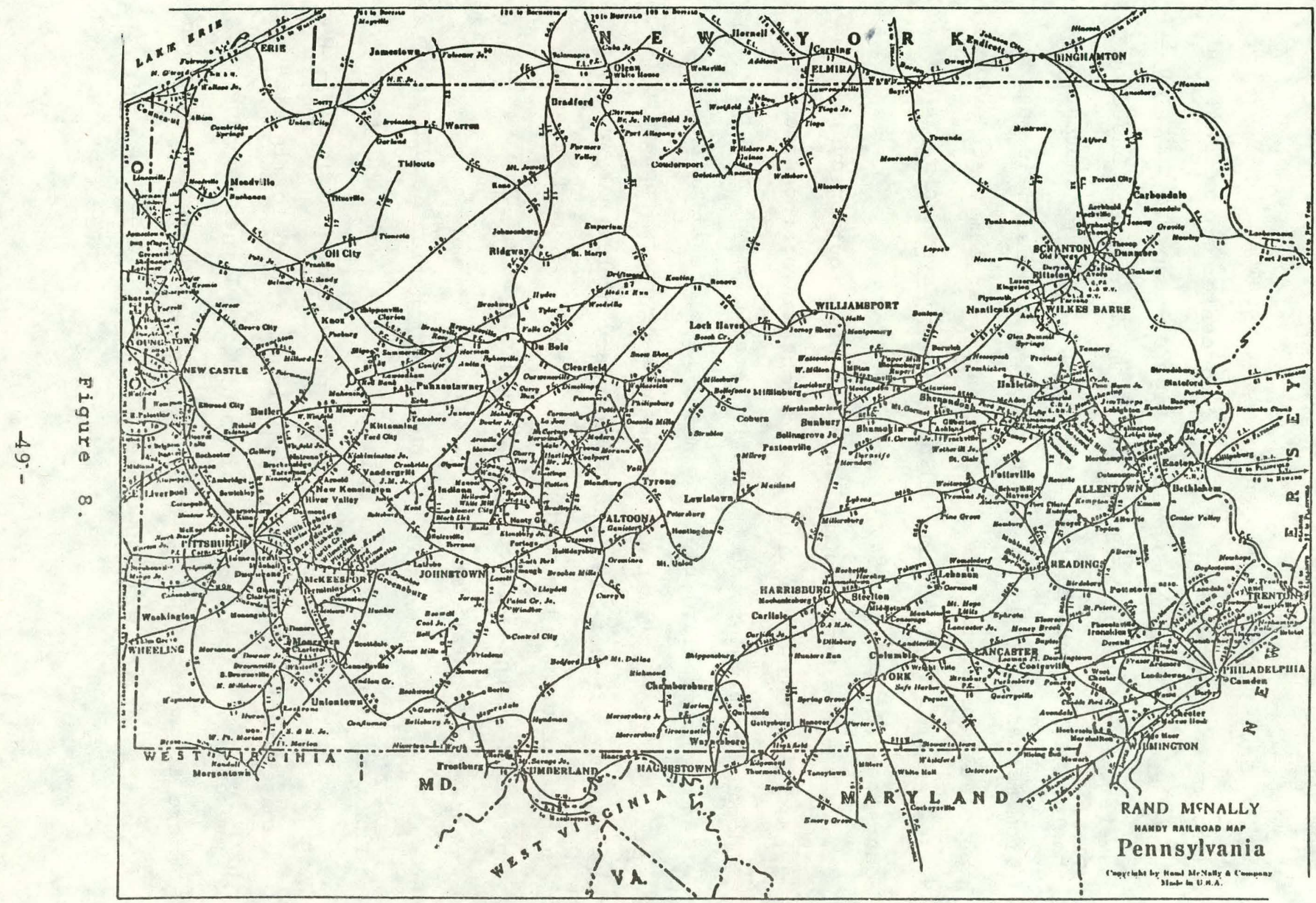


DISTRIBUTION

Investigations (Appendix 4) of possible distribution systems for methanol as an auto fuel center around railroad tank car or pipeline movement. Figure 9 shows a distribution system comprised of both systems. The concept is based on the initial growth of the market using rail transportation from methanol synthesis plant to bulk terminal near major population centers. As a sufficiently large market develops, pipelines may be constructed between the synthesis plants and the bulk terminals.

It has been assumed that the distribution system will move the methanol separately from the hydrocarbon fuel even though the final product that is retailed may consist of a blend. Eventually, blending may take place at an earlier stage in the system but for the present there appear to be advantages in not creating unnecessary problems by attempting to transport the mixtures. A blend, if used, can be produced at the service station and dispensed by a mixing pump from separate storage tanks.

The conventional gasoline aistribution ${ }^{10}$ employed by Exxon in their study was updated to 19794. This analysis took into consideration known data on petroleum product distribution and retailing plus recognizing the need to minimize the presence of water, the requirements for larger storage and more truck capacity, and the need for adequate compensation for the service station dealer. Using statistical data on 
METHANOL DISTRIBUTION SYSTEM

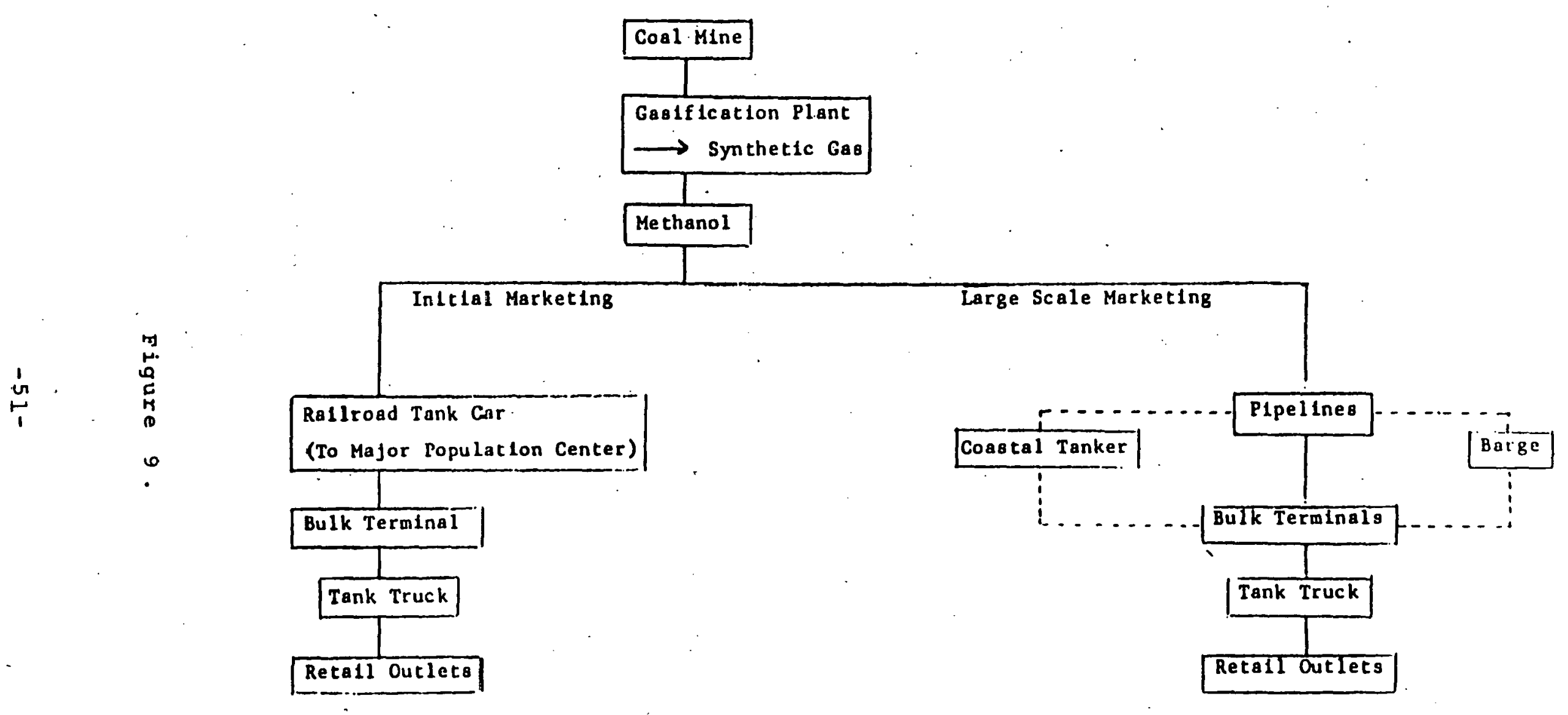


the purchasing power of the dollar as measured by both wholesale and retail prices plus the price index for rail freight, the earlier study's results were adjusted from 1974 to 1979 as follows:

Rail freight from synthesis plant to bulk terminal

$$
\$ 1.13 / 10^{6} \mathrm{Btu}
$$

Distribution and marketing from bulk terminal

$$
\begin{array}{lr}
\text { Distribution and marketing of gasoline } & 1.79 \\
\text { Cost of keeping system dry for methanol } & .33 \\
\text { Larger bulk storage, tank trucks, and } & .08 \\
\text { increase in trequency of deliveries } & \\
\text { Additional service station investments } & .16 \\
\text { and additional dealer margins } &
\end{array}
$$

Total distribution cost from methanol synthesis plant to service station pump (1000 mile rail trip)

There is shown on Figure 10 a plot of the total

distribution costs as a function of the distance between the synthesis plant and bulk terminal.

The production of methanol in Pennsylvania from coal located in the anthracite regions eliminates the need for long freight hauls. Thus, the cost of railroad tank car movement (Figure 9) from the plant to the major population centers can be virtually eliminated since the demand area is contiguous with the production area. This, effectively, eliminates approximately $\$ 1.00$ per million Btu from the distribution costs. 
Figure 1:e

1979 TOTAL DISTRIBUTION COST FOR METHANOL AS A FUNCTION OF DISTANCE OF SYNTHESIS PLANT FROM BULK TERMINAL

$\$$ per rilition Btu

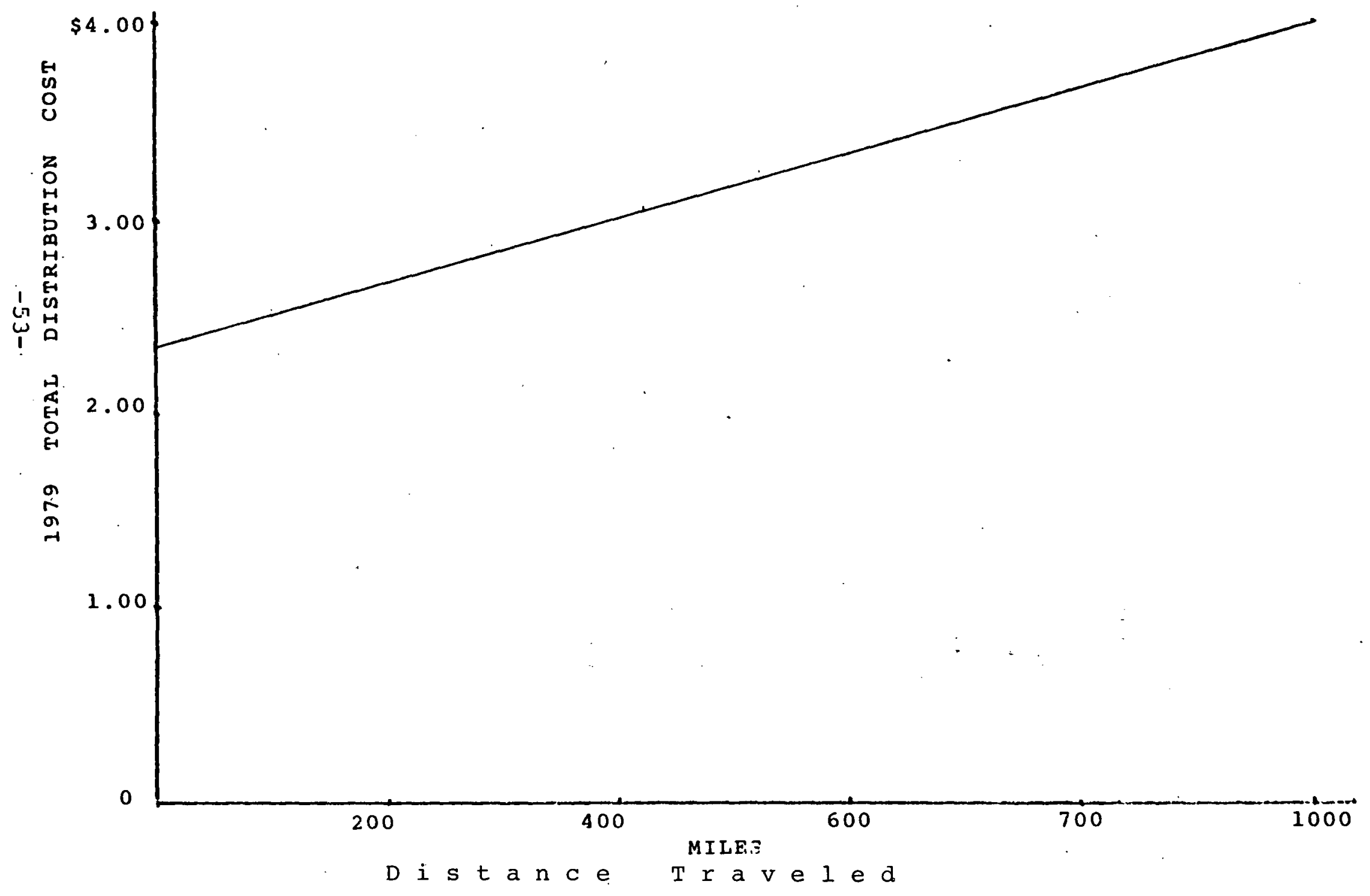


ENVIRONMENTAL IMPACT

In the gasification of coal, it is possible using current technology and practices to reduce each unit of the process to an environmentally acceptable level. For practical purposes such a control technology would be both difficult and expensive to execute. Most gasifying processes utilize large quantities of water and are net users. Since recycling of effluents is not only desirable environmentally but also proves to be economic, the treating and recycling with little or no discharge can be engineered into the design.

Gaseious emissions can be controlled to meet the current environmental standards, the particulates can be controlled or eliminated, and the solid wastes can be managed to avoid unfavorable environmental effects. There can be large quantitles of ash in llie form of jlag from the gasifier sinse anthracite has a high ash content. In the course of discussions with the Anjomar group at Wilkes-Barre, they have made plans, that have been accepted environmentally, to distribite the residues trom their coal prepalalivir plant to various operations that are filling abandoned mines and mine voids throughout the area. A similar arrangement would be considered for the disposal of the gasifier ash.

substantial quantities of carbon dioxide and steam will be emitter by the gasifier but these should not have any objectionable environmental effects other than the visual presence of steam. As yet no definitive studies have arrived 
at a solution for the economic use of the excess carbon dioxide that is produced.

The cost of a sulfur recovery unit is included in the construction estimate in order to eliminate any unacceptable disposal to the environment. .

In terms of dollar costs, specific data were obtained from a number of Bethlehem Steel Mines corporation projects in which coal mine wastes were disposed of above ground. This approach is considered in view of a National Academy of Sciences study that pointed out that under unusually favorable conditions it would cost at least $\$ 1$ to $\$ 4$ per ton of coal to dispose of wastes underground (1975). Bethlehem found that in 1975 it cost as low as $\$ 0.16$ per ton-mile and as high as $\$ .028$ per ton-mile to truck coal mine and coal plant preparation wastes to disposal sites. The sites were about a mile from the mine or preparation plant and quantities as high as 1000 tons per day were being mined. Tf this waste had to be spread and compacted, the cost ranged from $\$ 0.03$ per ton to as high as $\$ 0.20$ per ton with an average of $\$ 0.11$ per ton. In this case, spreading and compacting consisted of flattening the top surface of the bank or pile and leaving the sides to slope at the angle of repose of the material.

If a part of the coal preparation plant wastes and the gasifier wastes are to be disposed of above ground, consideration may have to be given not only to spreading and 
compacting the wastes but also to applying soil cover, spreading and compacting the soil, and planting of grass and trees with a certain amount of fertilizer. A number of mining companies use the trucks carrying the soil to spread and compact it to a degree as they travel back and forth over the previously dumped material. However, the main spreading is usually accomplished with bulldozers.

At a particular site of a Bethlehem mine, a 75 acre ${ }^{13}$ plot has deposits of 8 million tons of coal mine refuse. This is about $16 \%$ of the 50 million tons of coal produced by the mine. During the preceding ten years betore mine clusing, 1100 tons of refuse from the coal preparation plant werc produced daily and moved to the disposal site in 10 trucks, and with front end loaders it was then leveled and compacted. It was estimater by the company that the hauling, spreading, and compacting cost about $\$ 0.31$ per ton of retuse. The suil to cover this 75 acres was obtained from company property. Each acre was covered with 3300 tons at a cost of $\$ 833$ per acre for the soil, transportation, spreading and compacting. The company's estimate was $\$ 0.28$ per ton to handle this total of 250,000 tons of soil cover. The total cusl for the dicposal and reclamation was $\$ 268,000$. A 125 billion Btu per day output gasifier and coal preparation plant would produce about 18 million tons of refuse annually. Updating Bethlehem's costs to 1979 and adjusting for the larger volume of material, approximately $\$ 0.03$ per million Btu output would 
be the cost of disposing of the ash and preparation plant solid wastes and reclaiming the disposal site. It must be recognized that the cost of each disposal and reclamation project must be estimated on its own specific characteristics since there is a wide variation in each. 
SOCIOLOGICAL AND INSTITUTIONAL IMPACTS

Pennsylvania has a favorable attitude toward projects that will utilize its natural resources and particularly, when the program will re-actuvate an industry that has suffered economically for a number of years. The citizenry and state organizations are well aware of the importance of proceeding further with the long-standing efforts to reclaim the land and dispose of the coal refuse. The impact these deposits have had on the regional economy is well known. Until recently, many of the refuse banks had been burning which had added greatly to contamination of air and water resources. Although most of the refuse banks are privately owned, there have been moves by owners to donate some of the banks for filling mine voids in order to clear their land and realize 1ts pulential coonomis value. Since a large fraction of the refuse is located within two miles of the traffic centers of incorporated communities, the land valucs oan bo expected to appreciate considerably with the removal of the material. Other factors that have contributed to the disposing of some of the waste banks by their owners have been the initiation of fires which have proved to be costly to extinguish.

The Atomic Energy Commission in the course of designing a 5000 tons per day methanol plant using coal as the raw material developed a manpower table for the construction and 
also the operation of the plant. The AEC's estimate of the field construction manhours for the gasifier plant would be $6,830,000$ hours which is equivalent to 3,400 man years. The methanol synthesis plant, the AEC calculated, would require $1,356,000$ hours of field construction which is equivalent to 678 man years. Finally, the operations of the gasifier and the synthesis plant would require a total of 692 full time personnel. The impact of these requirements for labor would have a favorable effect on communities whose total population is about 750,000 and whose economy requires additional jobs.

There appear to be no problems of shifting populations owing to the development of a coal conversion facility, and the type of skills required by any of the operations can be readily learned by the average individual with proper train-. ing.

No major disruption of the land is planned. There would, however, be increased traffic owing to the movement of Iarge shipments of coal into the plant and the hauling of methanol out of the synthesis plant. 


\section{APPENDIX 1 .}

Anthracite Reserves In-Place in Pennsylvania

The three counties which contain the major reserves of anthracite together with the quantities are as follows:

$\begin{array}{ll}\text { Schuylkill county } & 9,900,000,000 \text { tons } \\ \text { Luzerne County } & 1,700,000,000 \\ \text { Northumberlald County } & 1,900,000,000\end{array}$

It has been estimated that probably $50 \%$ of this coal is recoverable. 
STANDARD ANTHRACITE SPECIFICATIONS 17

Test Mesh-Round Oversize Indersize Max. Impurities.

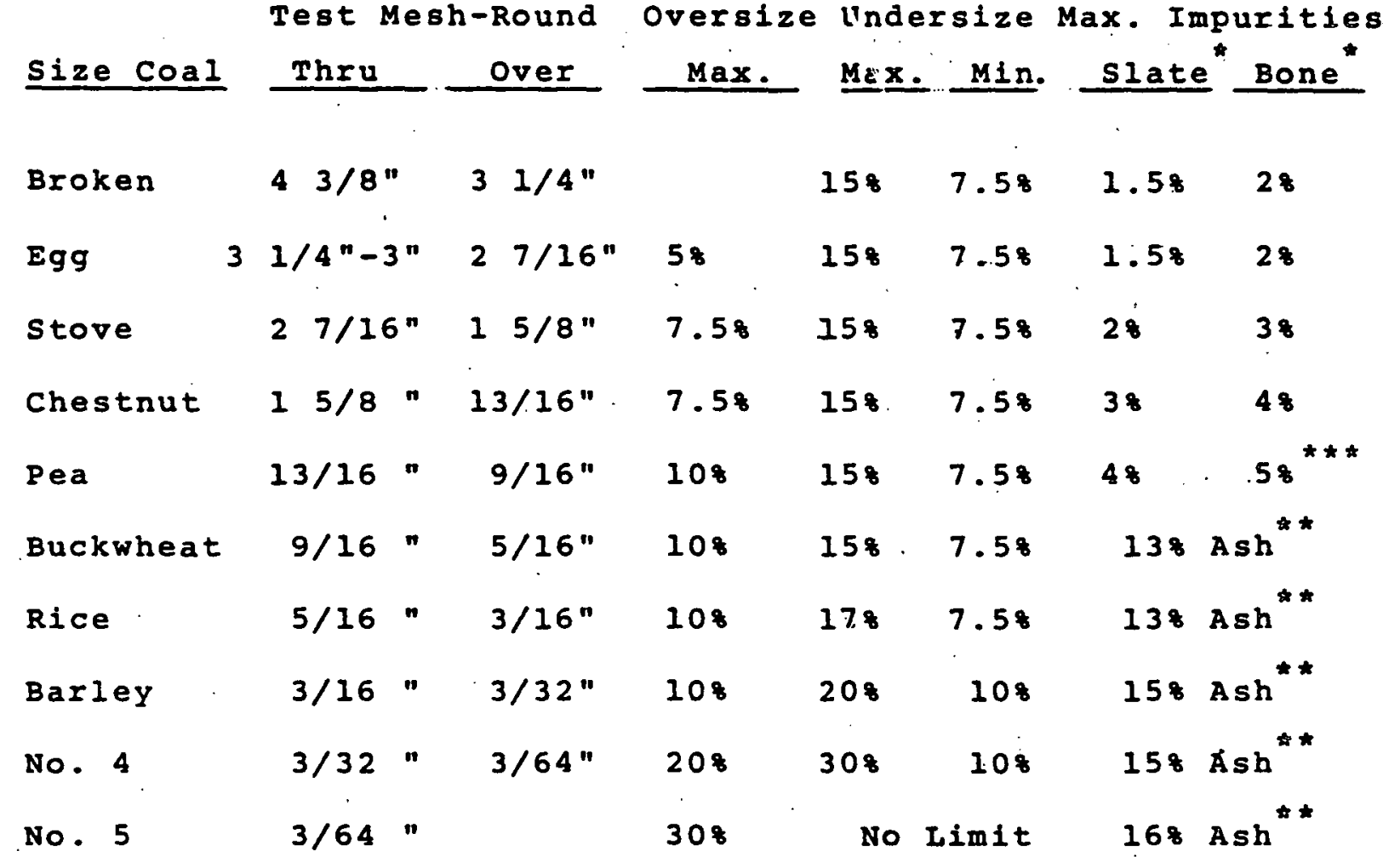

* When slate content in the sizes from Broken to chestnut, inclusive, is less than the above standards, bone content may be increased by 1 1/2 rimes the decrease in the slate content under the allowable limits, but specified slate content shall not be exceeded in any event. Bone is defined as any material that has $40 \%$ or more, but less than 758 fixed carbon. Slate is defined as any material that has less than 408 fixed carbon.

* Ash determinations are on a dry basis

** Pea-Maximum impurities are 48 slate, 58 bone or 128 ash Maximum ash in Broken through Chestnut is 118.

A tolerance of 18 is allowed on the maximum percentage of undersize and the maximum percentage of ash content. 


$$
\text { APPENDIX } 3 \text {. }
$$

PENNSYLVANIA POWER \& IIGHT COMPANY $65.66,67$

$$
\text { Combustion Turbines }
$$

Pottsoille

wilkes-Barre

Hazleton

scranton

milliameport

Allentown

Martins Creek

Lock Haven

sunbury

Harrisburg

TOTAL
37.2 Megawatts

32.0

32.0

29.3

32.0

64.0

94.3

18.6

47.2

101.2

487.8 Megawatts 


\section{APPENDIX 4 .}

104

In a study conducted by Exxon Research and Engineering Company for the U. S. Environmental Protection Agency, it was determined that the distribution costs of petroleum products from the refinery to the bulk terminal, and tank-truck delivery to the service station plus retailing margins totaled approximately 11 cents per gâllon. In order to translate these distribution costs into those for distributing methanol, a number of aspects rere given major consideration.

Owing to methanol's affinity for water, the distribution system design would reflect additional costs associated with keeping the system dry... Exxon's cost for distributing avaiation fuels which have severe requirements as to the presence of water are approximately 208 higher than the corresponding costs for auto gasoline. Exxon considered a 408 penalty on distribution costs as a reasonable estimate to use for methanol distribution.

There is a need for larger bulk storage and additional tank trucks as compared to present gasoline systems that are distributing an equivalent amount of energy. The lowest cost system would be a combination of larger bulk and retail tanks plus additional truck trips to make deliveries. The results of the study showed that this additional cost is of the order of 28 to 38 of the total marketing and distribution 
costs.

A third consideration involved the service station dealer. An additional investment in tanks, pumps, and equipment is needed as a result of marketing two fuels. This increases his retailing costs. Exxon estimated that based on a $40 \%$ capital recovery per year on the additional investment, approximately $\$ 0.05$ per million Btu would be added to the distribution cost.

An additional cost relates to llé servioo station dealer's margin which is based on gallons sold. With methanol he will process two gallons for each gallon of gasoline replaced. Consequently, he is now pumping twice the volume of material although the energy content has not changed. Preliminary calculations indicated that an additional $10 \%$ margin for the dealer above thal justified by his increased investment might be feasible and acceptable.

The distribution of methainol from the synthesis plant to the bulk terminal is a major item of cost. Based on the rail alternative, current freight for coal, which is equivalent on an energy weight basis, is approximately $\$ 10.00$ per ton per 1000 miles. An estimate of $\$ 0.60$ per million Btu was made based on moving the methanol over a 1000 mile route from Wyoming coal fields.

In order to arrive at a value for the distribution of methanol, the Exxon study added to the known distribution 
costs of gasoline, these additional costs which relate specifically to methanol. The overall cost arrived at was :

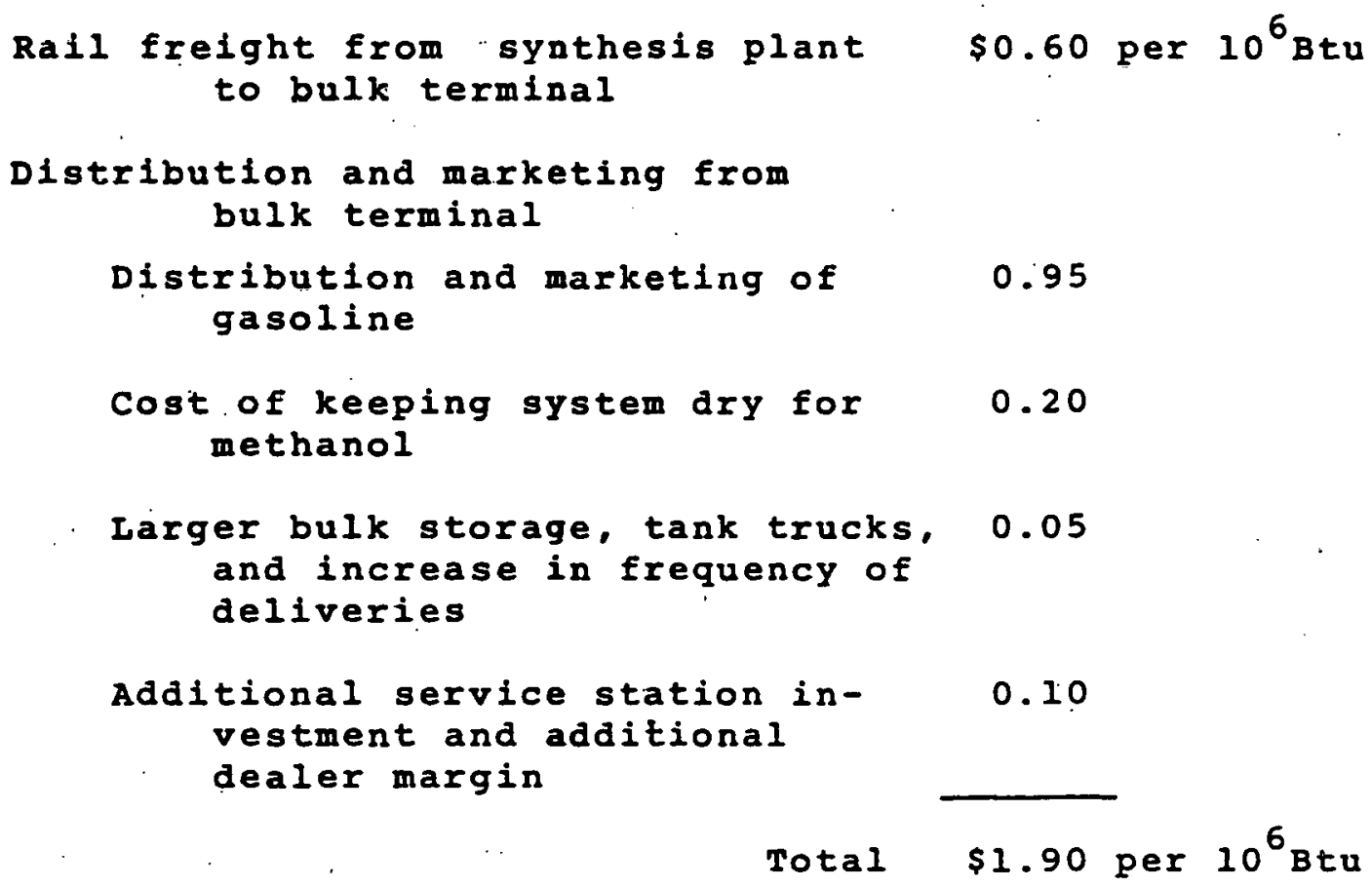




\section{BIBLIOGRAPHY}

1. S. Nearing, Anthracite, The John C. Winston Company, Philadelphia, 1915.

2. J. D. Sisler, T. Fraser, and D. C. Ashmead, Anthracite Culm and silt, Pennsylvania Bureau of Publication, Bull. M-12, Harrisburg, 1928.

3. Chevron World-1980/winter, Standard oil of California, San Francisco

4. American Petroleum Institute, Alcohols-A Technical Assessment of their Application as Fuels, Publieation 4261, Washington, D.C. July 1976.

5. Shell Shareholder News, Shell Oil Company, Houston, Texas, August 1979 .

6. H. Jaffee, F. Endelman. J. R. Hightower, B. Berger, W. Crothers, A. Pasternak, and R. Carter, Methanol from Coal for the Automotive Market, U.S. Atomic Energy Commission Report, Feb. 1, 1974.

7. W. J. Barr and F. A. Parker, The Introduction of Methanol as a New Fuel into the United States Economy, Foundation for ocean Research, San Diego, March 1976 .

8. R. B. Saward, Saward's Annual, 1952-1964 New York

9. F. W. Saward, Saward's Annual, 1934 New York

10. Minerals Yearbook 1973 Volume II, U.S. Department of the Interior, Washington, D.C.

11. Minerals Yearbook 1975 Volume I, U.S. Department of the Interior, Washington, D.C.

12. Keystone Coal Industry Manual 1975 - 1978, McGrawHill Inc., New York

13. W. S. Doyle, Deep Coal Minlny, Waste Disposal Technology, Noyes Data Corporation, Park Ridge, N.J. 1976

14. D. Webber, Methanol: A New Wrinkle or Two, Chemical Business, October 15, 1979. 
15. National Academy of Sciences, Underground Disposal of Coal Mine wastes, Report to the National science Foundation, Washington, D.C. 1975.

16. National Coal Association, Coal Facts, Washington, D.C. $1974-1975$.

17. J. C. MacCartney and R. H. Whate, Pennsylvania

Anthracite Refuse, Information Circular 8409, U.S. Buxeau of Mines, Washington, D.C. 1969 .

18. W. T. Malenka and R. J. Brennan, Experimental Longwall Mining in a Pennsylvania Anthracite Mine, U.S. Bureau of Mines, Report of Investigation 67451966.

19. A. P. Pipilen, M. Weintraub, and A. A. Orning, Hydraulic Transport of Coal, Report of Investigation 6743, U.S. Bureau of Mines, Washington, D.C. 1966.

20. Berger Associates, Evaluation of Mining Constraints to the Revitalization of Pennsylvania Anthracite, Harrisburg, PA March 1975

21. Project Independence-Interagency Coal Task Force, U.S. Department of the Interior, washington, D.C. November 1974 .

22. Surface Mining Control and Reclamation Act of 1977, Public Law 95-87 95th Congress Washington, D.C. August 3,1977 .

23. Anthracite Division, Annual Report, Department of Mines, Commonwealth of Pennsylvania 1939-1945.

24. Future coal supply for the world Energy Balance, Third International Institute for Applied systems Analysis Conference on Energy Resources, Moscow 1977. Pergamon, London 1979.

25. R. M. Jimeson, Methacoal Enhances the Transportation and Uses of Coal Resources, Third International Institute for Applied systems Analysis Conference on Energy Resources, Moscow 1977.

26. H. de Ruiter, Transport of Coal by Pipeline, Third International Institute for Applied systems Analysis Conference on Energy Resources, Moscow 1977.

27. Project Independence-Interagency Task Force on Energy Conservation, Council on Environmental Quality, Washington, D.C. November 1974. 
28. R. H. Whaite, Anthracite Mechanical Mining Investigations, Report of Investigations 5273, U.S. Bureau of Mines Washington, D.C. November 1956.

29. MESA Coal Refuse Disposal Facility Inspection Manual, U.S. Department of the Interior, Washington, D.C. 1975.

30. R. J. Evans and J. R. Bitler, Coal Surface Mining Reclamation Costs, Information Circular 8695, U.S. Bureau of Mines, Washington, D.C. 1975 .

31. E. D'Appolonia Consulting Engineers Inc., Engineering and Design Manual-Coal Refuse Disposal Facilities, Mine Enforcement and Safety Administration, U.S.

Department of the Interior, washington, D.C. 1975.

32. J. W. Lincoln, Methänol \& OLher ways Arnund the Gas Pump, Garden Way Publishing, Charlotte, VT 1976.

33. R. L. Gordon, Coal in the U. S. Energy Market, Lexington Books, Lexington, MA 1978 .

34. Resources for the Future, U. S. Energy Policies, An Agenda for Research, Johns Hopkins Press, Baltimore 1968 .

35. U. S. Senate, Report by subcommittee on synthetic Fuels, Synthetic Fuels, U.S. Government Printing Office, Senlember $37,1979$.

36. National Academy of Sciences, Coal as an Energy Resource, Washington, D.C. 1977 .

37. R. P. Larkin and G. L. Peters, A Method for Estahlishing Priorities for the Removal of Anthracite Coal Refuse in Northeastern Pennsylvania, Proc. Assoc. Amer. Geogr. 1974.

38. A. W. Martin Associates, Relationship between underground mine water pools and subsidence in the northeastern Pennsylvania anthracite flelds, Appalachian Regional Commission, Washington, D.C. 1975.

39. Wahler Associates, Reconnaissance Survey Report of - Coal Mine Refuse Dumps and Impoundments state of Pennsylvania, Palo Alto, CA 1974.

40. J. W. Leonard and D. R. Mitchell, Editors, Coal Preparation, American Institute of Mining, Metallurgical and Petroleum Engineers, Inc. New York 1968 . 
41. J. A. Vaughan, Anthracite, Mineral Facts and Problems, U.S. Bureau of Mines Bulletin 6301965 .

42. Department of Environmental Resources, Commonwealth of Pennsylvania, Annual Report on Mining, $0 i l$ and Gas and Land Reclamation and Conservation Activities, Harrisburg, PA 1978 .

43. V. A. Danielson and D. H. White, Jr., Waste Disposal Costs at Two Coal Mines in Kentucky and Ala-. bama, U.S. Bureau of Mines Information Circular 84061969.

44. Council on Environmental quality, Energy and the Environment, Washington, D.C. August 1973.

45. U. S. Bureau of Mines Staff, Strippable Reserves of Bituminous coal and Lignite in the United states, Information.Circular 8531, U. S. Department of the Interior, washington, D.C. 1971.

46. P. A. Hamilton, D. H. White, and T. K. Matson, The Reserve Base of U. S. Coals by Sulfur content, U. S. Bureau of Mines Information Circular 8693 1975 .

47. C. E. Bagge, The EConomic Viability of synthetic Fuels from coal, World Coal Conference, London, September 11, 1975.

48. U.S. Bureau of Mines, Wilkes-Barre, PA, Verbal communication with Ivor Williams relative to coal preparation plants. 1980.

49. U.S. Bureau of Mines, Schuylkill Haven, PA, Verbal communication with $W$. T. Malenka relative to anthracite gasification tests. 1980.

50. U.S. Bureau of Mines, Wilkes-Barre, PA, Verbal communication with F. Andreuzi relative to anthracoal refuse and coal preparation plants. 1980.

51. U.S. Bureau of Mines, Denver, Co, Verbal communication with J. Colaizda relative to anthracite deosits, mines, and mine refuse in the western states 1980 .

52. U. S. Bureau of Mines, Denver, CO, Verbal communication with $\mathrm{R}$. $\mathrm{H}$. Whaite relative to the anthracite refuse banks and silt ponds and the disposal of these wastes 1980 . 
53. Anjomar Corporation, Inkerman, $P A$, Verbal communication with Anthony Giarratano, President, relative to coal preparation plant under construction at Inkermann 1980 .

54. R. E. Morgan, J. W. Eckard, J. Ratney, and A. F. Baker, Lurgi-Gasifier Tests of Pennsylvania Anthracite, U.S. Bureau of Mines Report of Investigations 5420, 1958 .

55. J. Cooperman, J. D. Davis, W. Seymour, and W. L. Ruckes, Lurgi Process: Use for Complete Gasification of Coals with steam and oxygen under Pressure, U. S. Bureau of Mines Bulletin $498 \quad 1951$.

56. R. H. Griffith and F. J. Dent, Research Program of the Birmingham Research station, British Gas Council Research communicalion GC. $8 \quad 1853$.

57.

D. Hebden, R. F. Edge, and K. W. Foley,

Investigations with a Small pressure Gasifier, British Gas Council Research Communication GC-14 1954.

58. Civil Action No. 78-0224-B, United States District Court for the western District of Virginia, Memorandum opinion relative to the unconstitutionality of varlous provisions of the surface Mining control and Reclamation Act of 1977, Virginia surface Mining and Reclamation Assoc. Inc. vs. Cecil D. Andrus, Sec. Department of the Tnterior et al Jan. 3, 1980 .

59. Wilmot Engineering Company, white Haven, PA, Verbal communication with Harold Jeppsen rclative to the engineering design of the Aljomar coal refuse preparation plant 1980 .

60. W. G. Schlinger, Development and Commercialization of the Texaco Coal Gasification Process, Sixth Annual International Conference on Coal Liquefaction and Conference to Electricity, Pittsburgh, PA, July 31 - August $2,1979$.

61. W. G. Schlinger; J. Falbe, and R. Specks, Coal Gasification for Manufacture of Hydrogen, Amertcan Chemical soclety and Chemical sociaty of Japan congress; Hononlulu, April $1-6,1979$.

62. R. D. Klapatch and G. E. Vitti, Gas Turbine Combustor Test Results and Combined Cycle system, ASME Gas Turbine Conference \& Products show, Zurich, Switzerland, March 30 - April 4, 1974 . 
63. Texaco Inc.. Verbal communication with W. G. Schlinger, Los Angeles, CA, on Cool Water Coal Gasification Project, Daggett, California, Oct. 4, 1979.

64. Texaco Inc. and Southern California Edison Company, Cool Water Coal Gasification Project-An opportunity and a Challenge, Rosemead, CA, and White Plains, New York 1979 .

65. Federal Power Commission, Gas Turbine Electric Plant Construction Cost and Annual Production Expenses, Washington, D.C.

66. Pennsylvania Power \& Light Company, Uniform Statistical Report 1978, Allentown, PA 1978.

67. Moody's Investors Service Inc., Moody's Public Utility Manual, New York 1978.

68. U.S. Federal Highway Administration, Highway statistics, Washington, D.C. 1979 .

69. Resource Planning Associates, Coal Transportation, Ozarks Region Energy Alternatives Study, Mathtech, Inc., Princeton, N.J. April 1977 .

70. U.S. Bureau of the Census, Current Population Reports, Series P-25, washington, D.C. 1979.

71. R. Detman, Economics of Six Coal-to-sNG Processes, Hydrocarbon Processing, p. 115, March 1977.

72. T. Wett, SNG from Coal Involves Big Projects, The Oil and Gas Journal, p. 131, June 25, 1973;

73. S. Katell and L. G. White, Clean Fuels from Coal are Expensive, Hydrocarbon Processing, p. 85, July 1976 .

74. J. K. Paul, Editor, Methanol Technology and Application in Motor Fuels, Noyes Data Corporation, Park Ridge, N.J. 1978 .

75. D. H. Eastiand, Fuel and Energy Uses of Methanol, second Annual symposium on Coal Gasification and Liquefication, Pittsburgh, August 5, 1975 .

76. U.S. Congress, House of Representatives Hearings on Coal slurry Pipeline Legislation, Serial No. 94-8, G.P.O., Washington, D.C. March 19 - December 5, 1975 . 
77. M. Goodman and E. Bailey, Synthetic Medium BTU Gas via Winkler Process, Fourth Annual International Conference on Coal Gasification, Liquefaction \& Conversion to Electricity, University of Pittsburgh, August 2-4, 1977 .

78. I. N. Banchik, The Winkler Process, A Route to Clean Fuel from Coal, Davy Powergas Inc., Lakeland, Florida, December 1, 1975.

79. J. E. Franzen and E. K. Goeke, Gasify Coal for Petrochemicals, Hydrocarbon Processing p. 134 November 1976 .

80. M. B. Sherwin and M. E. Frank, Make Methanol by Three Phase Reaction, Hydrocarbon Processing, p. 122 Noviember 1976 .

81. I. N. Banchik, T. K. Subramaniam, and J. H. Marten, Pressure Reaction Cuts Gasification Costs, Hydrocarbon Processing, p. 121 March 1977.

82. W. L. Nelson, How Much to Deliver and Market Gasoline?, The Oil and Gas Journal, p. 139 August 23,1976 .

83. Dravo Corporation, Handbook of Gasifiers and Gas Treatment Systems, U.S. Energy Research and Development Administration, Washington, D.C. Feb. 1976.

84. Utah International, Verbal communication with J. P. Messineo relative to mining coal resources in New Mexico, september 28, 1073.

85. Utah International, Verbal communication with R. N. Hickman relative to production and costs of western coals, San Francisco, CA, September 28, 1979.

86. Utah International, verbal communisation with $b . w$. Tarleton concerning availability of Utah Int'l coal, San Francisco, CA, Séptember $28,1979$.

87. Kaiser Engineers Inc., Verbal communication with P. F. Irminger relative to the solids handing of the North Dakota lignite on the American Natural Gas Company project, Oakland, CA, Sept. 29, 1979.

88. Kaiser Engineers Inc.,Verbal communication with D. Keay on coal screening and preparation and screen ing of lignite, Oakland, CA, September 28, 1979. 
89. Fluor Engineers and Constructors Inc., Verbal communication with R. P. Schaaf on coal gasification plants, Irvine, CA, October 1,:1979.

90. Fluor Engineers and Constructors Inc., Verbal Communication with P. F. Mako on coal gasification systems and total energy community systems, Irvine, CA, october 1,1979 .

91. Texaco Inc., Verbal communication with E. T. Child on gasification of anthracite in the Texaco gasifier, New York 1980 .

92. Texaco Inc., Verbal communication with W. B. Crouch on ash fusion of anthracite in the Texaco gasifier, New York 1979 .

93. Chemical Construction Corporation, Mechanical Design of 5000 Tons per day Methanol Energy Plant, New York 1970 .

94. Lurgi MineralolTechnik Gmbh, Petrochemistry Division, Methanol by the Lurgi Low Pressure. Process, Frankfurt (Main), February 1976.

95. P. F. H. Rudolph, Processing of American Coals in a Lurgi Gasifier, Presented at Sixth Symposium on Synthetic Pipeline Gas, Chicago, October 28-30, 1974.

96. H. Hiller, The Lurgi Pressure Gasification, Presented at DGMK-Conference, Hamburg, F.R.G., January 10,1974.

97. H. Hiller, F. Marschner, and E. Supp, The Lurgi Low Pressure Methanol Process, Chemical Economy and Engineering Review, September 1971.

98. D. L. Hagen, Methanol: Its Synthesis, Use as a Fuel, Economics, and Hazards, Thesis submitted to the Faculty of the Graduate school of the University of Minnesota, December 2976 .

99. Mercer County, North Dakota, Coal Gasification Project, ANG Coal Gasification Company, ANR Gasification Properties Company and PGC Coal Gasification Company, Detroit, Michigan, May 5, 1977 .

100. A. Verma, From Coal to Gas, Chemtech, June 1978 and october 1978 .

101. El Paso Natural Gas Company, The Burnham Coal Gasification Complex, El Paso, TX, April 11, 1974. 
102. J. D. Oster, E. C. Glass, and A. L. Freeman, Report on a Proposed study of a Lignite-Fueled Methanol Plant, Minnkota Power Cooperative and Northern States Power Company March 25, 1977.

103. Bureau of Economic Analysis, U. S. Department of Commerce, Survey of Current Business, February 1976, February 1978, February 1980.

104. F. H. Kant, R. P. Cahn, A. R. Cunningham, M. H. Farmer, W. Herbst, and E. H. Manny, Feasibility Study of Alternative Fuels for Automotive Transportation, Exxon Research and Engineering Company June 1974 .

105. Gulf Oil Corporation, Why Does Gasoline cost So Much? Pittsburgh, PA SP\#15102 Feb. 1980.

106.- S. Strelzoff, Methanol: Its Technology and Economics, American Institute of Chemical Engineers, Progress Sysmposium Series No. 98, vol. 661970 .

107. E. F. Osborn, Clean Synthetic Fuels from Coal: Some Prospects and Projections, Annual Meeting of the API Division of Production, Denver, Colorado, April 9-11, 1973.

108. P. L. Rogersoil, Imperial Chemical Industries Low Pxessure Methanol plant, American Institute of Chemicai Engineers, Progress symposium serics No. 98, Vol. 661970 p. 28.

109. R. J. Kenard, Jr., and:N. M. Nimo, Present Methanol Manufacturing Costs and Economics Using the ICI Process, American Institute of Chemical Engineers, Progress symposium series No. 98, Vol. 661970.

110. U. S. Department of Energy, Washington, D.C., Verbal communication with S. Carlson, Division of Anthracite, relative to utility and industrial applications 1980 .

111. Mueller Associates Inc., A Comparison of Projected Electric Utility Peaking Gas Turbine Energy Requirements to Potential Alcohol Fuels Availability 1980-2000, Baltimore, MD March 1979.

112. The Aerospace Corporation, Project Plan for Reliability Fleet Testing of Alcohol/Gasoline Blends, Germantown, MD March 30, 1979. 
113. Asst. Secretary for Energy Technology, The Report of the Alcohol Fuels Policy Review, Raw Material Availability Reports, Washington; D.C. September 1979 .

114. Badger Plants Inc., Conceptual Design of a Coal to Methanol Commercial Plant, U.S. Department of Energy Contract No. Ex-76-C-01-2416, February 1978 .

115. Mobil Research and Development Corporation, Research Guidance. Studies to Assess Gasoline from Coal by Methanol-to-Gasoline and Sasol-Type Fischer-Tropsch Technologies, Princeton, N.J., August 1978 .

116. J. W. Eckerd, J. D. Clendenin, W. S. Sanner, and R. E. Morgan, Gasification of Bone Anthracite, Bureau of Mines Report of Investigation 5594, 19.60: 